\title{
Thermochemical Treatment of Metals
}

\author{
Frank Czerwinski
}

Additional information is available at the end of the chapter

http://dx.doi.org/10.5772/51566

\section{Introduction}

Surface engineering represents the technically attractive and economically viable method aimed at improving the superficial layer of materials. Since the material surface controls the service life in many applications, the objective is to develop a wide range of functional properties that are different from the base substrate including physical, chemical, electrical, electronic, magnetic or mechanical. Being a part of surface engineering, the thermochemical treatment employs thermal diffusion to incorporate non-metal or metal atoms into a material surface to modify its chemistry and microstructure (Fig. 1). The process is conducted in solid, liquid or gaseous media with one or several simultaneously active chemical elements. For majority of thermochemical treatments the mechanism includes a decomposition of solid, liquid or gaseous species, splitting of gaseous molecules to form nascent atoms, absorption of atoms, their diffusion into a metallic lattice and reactions within the substrate structure to modify existing or form new phases. Since in industrial scale processes the entire part is subjected to high temperatures, surface diffusion is superimposed on changes within the material volume that for some treatments may involve phase transformations and this adds to the complexity.

Historically, the thermochemical treatment was limited to machined parts, forgings and castings with an application in machinery, automotive, tooling, oil drilling, mining and defence [1]. The key processes covered nitriding, carburizing and their combinations. Similarly, steel was in practice the only material subjected to the modification. To enhance the process predictability and repeatability, the conventional gas nitriding was refined and the alternative technique of ion (plasma) nitriding was introduced. In quest for the perfect process, the plasma technology is still a subject of continuous improvement and developed techniques of post discharge nitriding or active screen plasma nitriding may serve as examples [2]. In the meantime, the thermochemical modifications included other processes such as boronizing, aluminizing, chromizing or thermo-reactive diffusion, exploring vanadium, molybdenum and other carbide-forming elements. Although they never achieved the application level of nitriding, they successfully serve many niche markets. 
In recent decades, an application of the thermochemical treatment expanded to alloys with exotic chemistries [3], nonferrous metals like aluminum [4] and also refractory metals. Numerous hybrid processes were developed where thermochemical diffusion is a part of the multi-step treatment involving coating, cladding, laser processing etc. While the conventional applications still dominate, it is seen an expansion of the thermochemical treatment to novel manufacturing techniques such as micro-scale fabrication, fuel cells [5] or electronics [6].

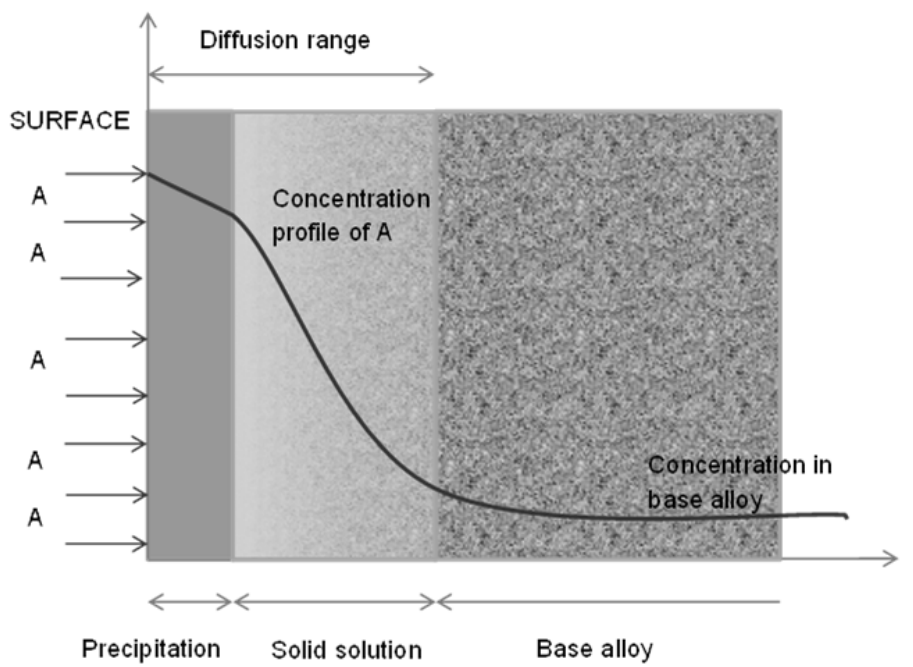

Figure 1. Principles of thermochemical treatment showing a distribution of the chemical element $\mathrm{A}$ inside an alloy along with typically modified sub-surface areas

This chapter covers major aspects of the thermochemical surface treatment of metals and alloys. A mixture of engineering fundamentals and recent global scientific developments should not only be useful for professionals from metallurgy and materials area but also for experts from other fields of engineering.

\section{Nitriding}

Nitriding has been and continues to be the major thermochemical treatment which along with ferritic nitrocarburizing represents the dominant volume of industrial surface modification technologies. The treatment leads to an incorporation of nitrogen into the surface of steel while it is in ferritic state. In commercial applications, the typical modified zone is up to $200-300 \mu \mathrm{m}$ thick, rarely exceeding $600 \mu \mathrm{m}$. Its impact on surface hardness distribution, in terms of the maximum value and penetration depth, as compared with other heat and thermochemical treatments, is shown in Fig. 2. There is no additional heat treatment required following nitriding and the component surface experiences an increase in hardness, wear resistance, improved corrosion resistance and fatigue life. 


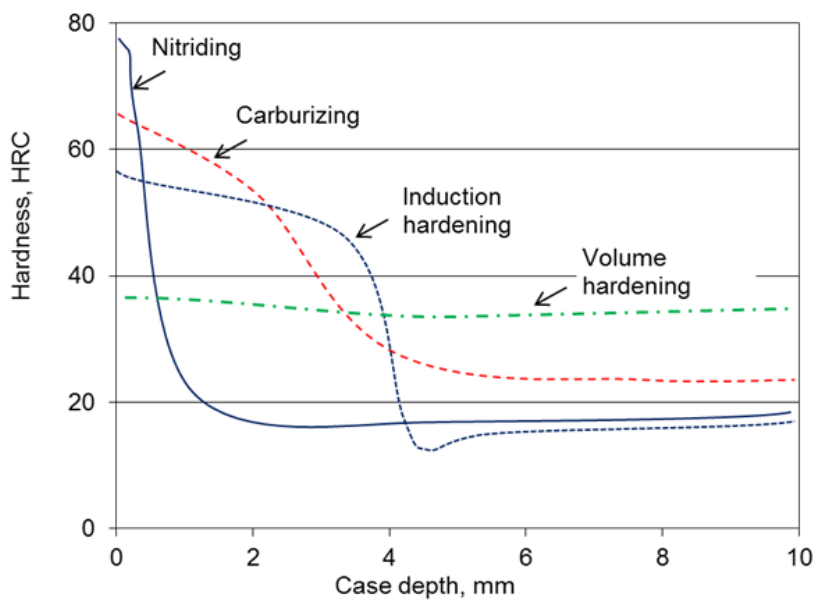

Figure 2. Hardness depth profiles for selected thermal and thermochemical treatments, emphasizing differences in the maximum hardness and penetration depth

\subsection{Nitriding technologies available at present}

To implement nitriding, several technologies, exploring different sources of nitrogen, were commercialized.

\subsubsection{Gas nitriding}

Gas nitriding was patented in 1913 and 1921, and is carried out usually at temperatures of $550-580{ }^{\circ} \mathrm{C}$ in a box furnace or fluidized bed in an atmosphere filled with partially dissociated ammonia [1]. The advantages of the fluidized bed are the near-ideal temperature uniformity through the entire gas-particle volume and fast heating rate [7]. For gas nitriding the fundamental reaction is the catalytic decomposition of ammonia to form the nascent (elemental) nitrogen:

$$
\mathrm{NH}_{3}=[\mathrm{N}]+3 / 2 \mathrm{H}_{2}
$$

The control parameters include time, temperature and gas dissociation rate. In production environment, the latter is periodically measured and adjusted. The inherent feature of conventional gas nitriding is that the superficial concentration of nitrogen cannot be precisely monitored. As a result the structure of nitrided layer and the entire process are often missing predictability and repeatability.

The controlled gas nitriding Nitreg®, employs a mixed-gas atmosphere, composed of ammonia and an additive gas [8]. As opposed to conventional gas nitriding, the process is controlled not by the dissociation rate but by a different parameter, called the nitriding potential of the furnace atmosphere. The nitriding potential is expressed as the ratio of partial pressures of ammonia and hydrogen: 


$$
K_{n}=\frac{p N H_{3}}{\sqrt{\left(p H_{2}\right)^{3}}}
$$

where: $\mathrm{pNH}_{3}$ is the partial pressure of ammonia and $\mathrm{pH}_{2}$ is the partial pressure of hydrogen

An advantage of effective control through the nitriding potential, expressing in more uniform nitrided case for complex geometries, is accompanied by general disadvantages of the gas process such as masking difficulties to prevent nitriding, requiring copper plating or painting with protective pastes and the special surface activation necessary for stainless steels or alloys generating a passive oxide films.

\subsubsection{Liquid salt nitriding}

Liquid nitriding, developed in 1940's, is conducted in the fused salt bath containing either cyanides or cyanates. A typical commercial bath is composed of a mixture of $60-70 \%$ sodium salts $\left\{96.5 \% \mathrm{NaCN}, 2.5 \% \mathrm{Na}_{2} \mathrm{CO}_{3}, 0.5 \% \mathrm{NaCNO}\right\}$ and $30-40 \%$ potassium salts $\{96 \% \mathrm{KCN}$, $0.6 \% \mathrm{~K}_{2} \mathrm{CO}_{3}, 0.75 \% \mathrm{KCNO}, 0.5 \% \mathrm{KCl}$ [ [9]. The commercial equipment for salt nitriding, along with gas and plasma technologies is shown in Fig. 3. The major advantage is the short cycle time due to intense heating and the high reactivity of the medium. Several methods exist to accelerate further the nitriding rate, such as bath additions of sulphur or melt pressurizing. Typically, for low-alloy steel the cycle time lasting $1.5 \mathrm{~h}$ at the operating temperature of 565 ${ }^{\circ} \mathrm{C}$ produces a case of $0.3 \mathrm{~mm}$ thick. The salt-bath technology has also a number of negative features, such as the bath toxicity and poor quality of the nitrided surface.

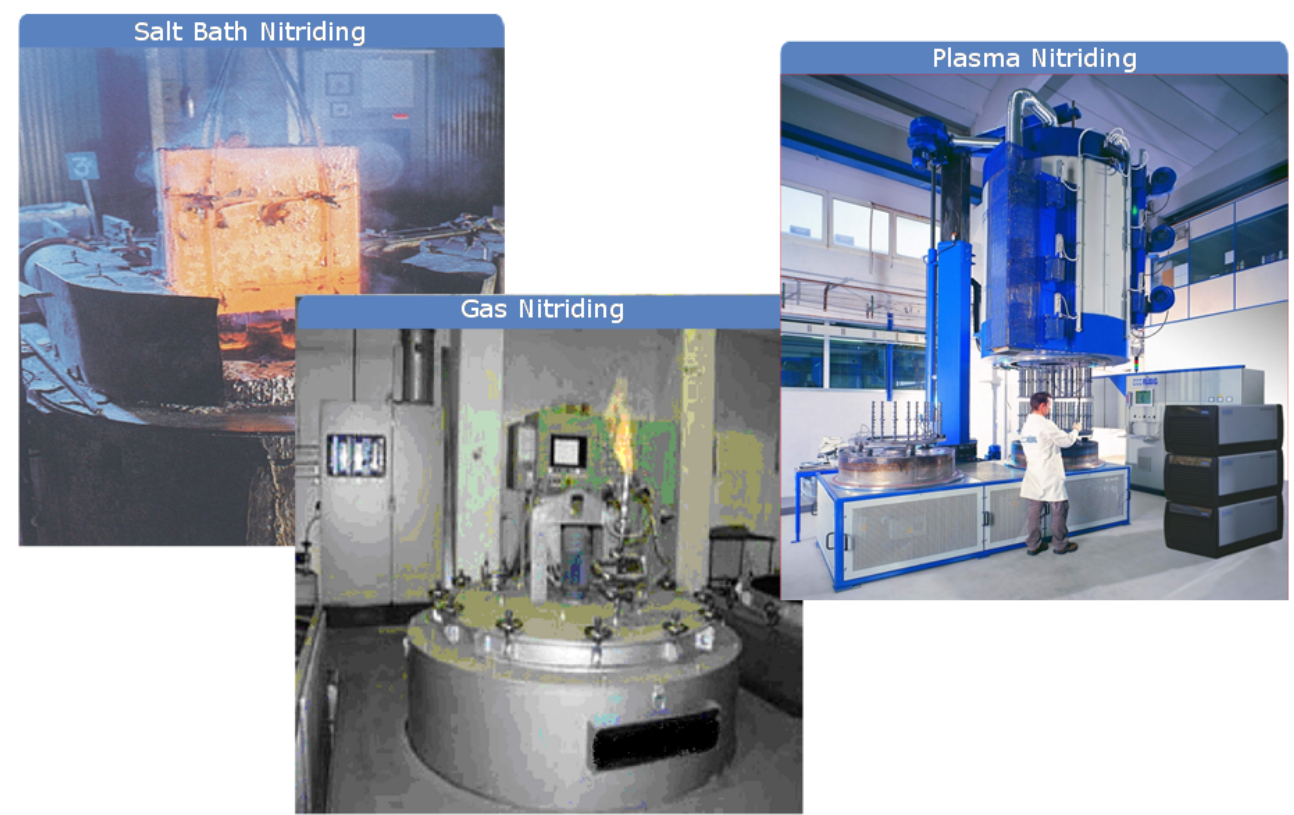

Figure 3. Commercial technologies of liquid salt bath, gas and plasma nitriding (with permission from Rubig $\mathrm{GmbH}$ ) 


\subsubsection{Plasma (ion) nitriding}

Plasma nitriding, called also ion nitriding, was invented by Wehnheldt and Berghause in 1932 but became commercially viable as late as in 1970's. It uses the glow discharge phenomenon to introduce nascent nitrogen to the surface of an alloy and its subsequent diffusion into subsurface layers [10]. An example of modern installation is shown in Fig. 4. Plasma is formed in a vacuum using a high-voltage electrical energy to accelerate nitrogen ions which bombard the alloy surface [11] (Fig. 5a). The advantages of ion nitriding include the low temperature, short saturation time and simple mechanical masking. The unique advantage is surface-activation sputtering. Due to the sputtering effect of positive ions in the glow discharge, the protective oxide, inherent for surfaces of stainless steels, aluminum or titanium alloys, is removed. Thus, nitrogen atoms can be moved from the plasma to the material sub-surface. In the conventional direct-current system the nitrided component is subjected to the high cathode potential and plasma forms directly on the component surface. This may create disadvantages such as the temperature non-uniformity with a possibility of overheating, sensitivity to the part geometry, causing edge effect and a possibility of surface damage due to arcing.

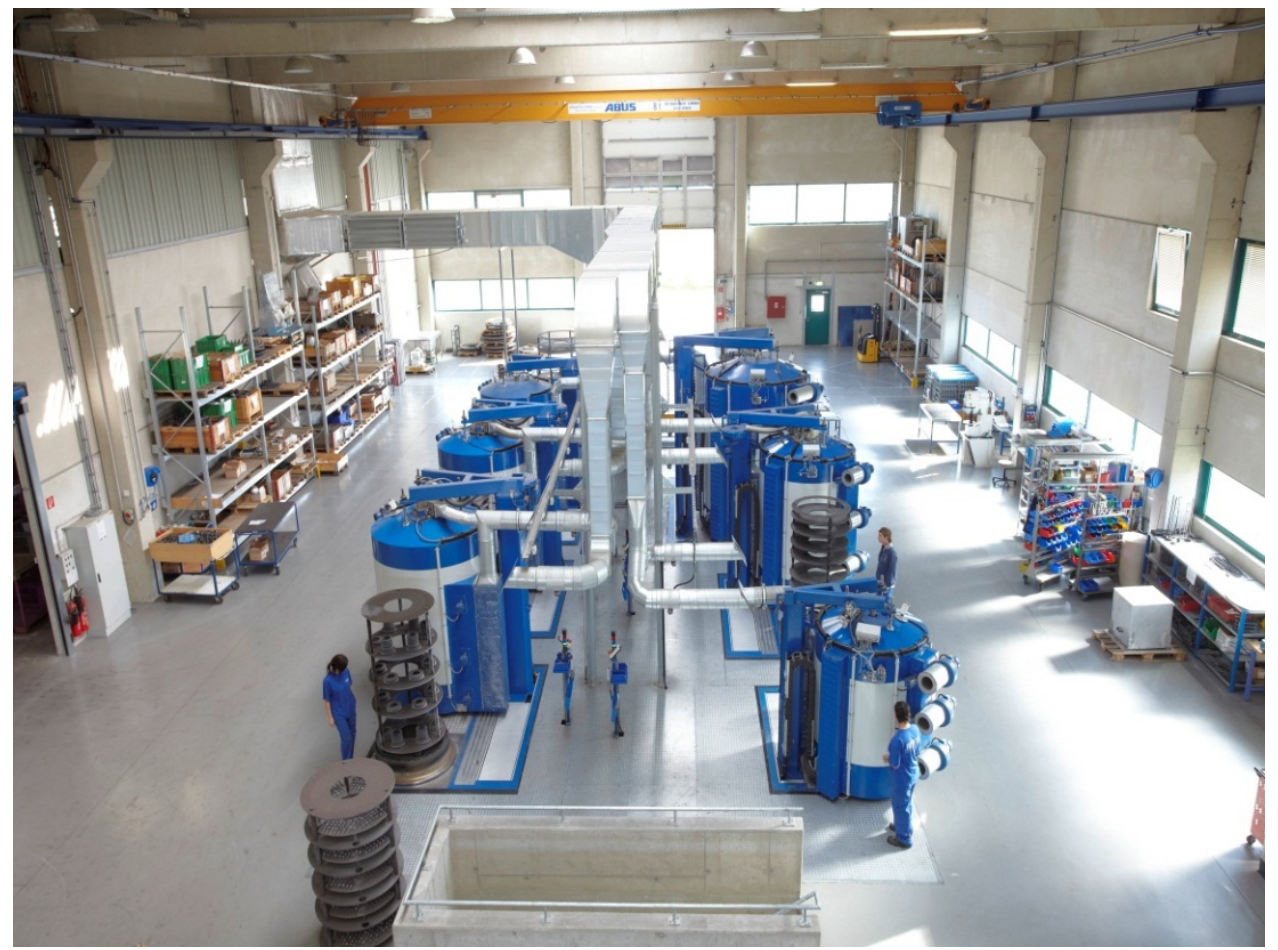

Figure 4. Modern line of commercial plasma nitriding (with permission from Rubig $\mathrm{GmbH}$ )

To overcome the latter limitation, different approaches were investigated. The post discharge nitriding, where the nitrided part at an electrically floating potential is kept at the nitriding 
temperature by use of an external heater, was so far not adopted by industry [12]. Another technique, called active screen plasma nitriding, was invented in 1999 and has some commercial applications [2]. As shown in Fig. 5b, an essence of the new process is in applying the high cathodic potential to a screen surrounding the nitrided part which becomes the real cathode, replacing in this role the nitrided part. Therefore, plasma forms on the active screen, heating it up. Then, a radiation from the screen heats the nitrided part to the required temperature [13]. The plasma, forming on the screen, is composed of a mixture of ions, electrons and other active nitriding species which are forced to flow over the nitrided part by the designed gas circulation. Thus, complex geometries obtain the uniform nitrided layer and even blind holes are affected by diffusion and effectively nitrided.

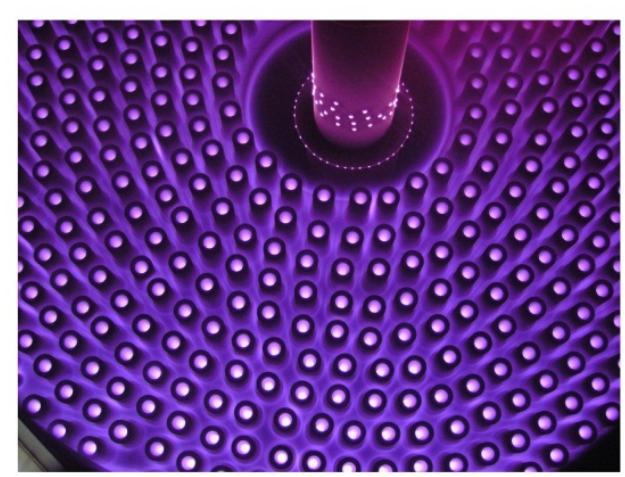

(a)

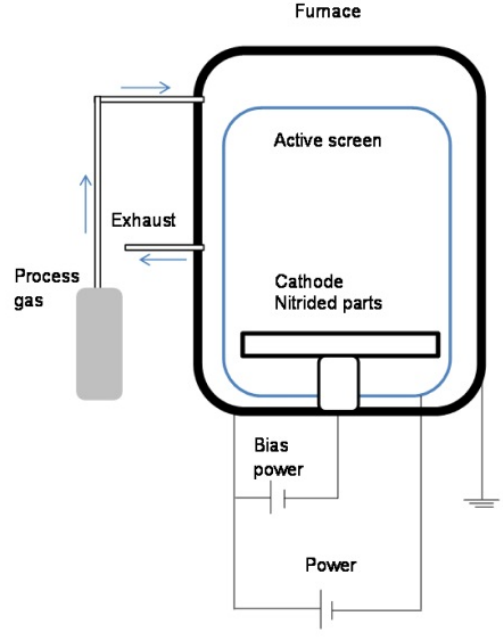

(b)

Figure 5. Plasma nitriding: (a) view of components during Ultraglow ${ }^{\circledR}$ process (with permission from Advanced Heat Treat Corp.) (b) schematics showing a concept of active screen plasma nitriding

\subsubsection{Laser nitriding}

In the last two decades, laser nitriding has been investigated as an alternative nitriding method [14]. As explained in Fig. 6, during a direct laser synthesis a material is placed in the reactive gas environment and irradiated with the laser light. Nitrogen is fed through a nozzle into the melt pool. On a time scale of hundreds of nanoseconds, the high intensity pulse-laser irradiation of $\mathrm{I} \approx 10^{8} \mathrm{~W} / \mathrm{cm}^{2}$ in ambient nitrogen atmosphere is capable generating of $1-1.5 \mu \mathrm{m}$ thick thick nitrided layer.

\subsubsection{Beam ion implantation}

At limited scale, beam ion implantation can be used to incorporate nitrogen into a material surface. The conventional ion beam implantation, applied at room temperature, is capable to 
modify chemistry of relatively thin layers of materials. While using a beam of nitrogen ions with an energy of up to $1 \mathrm{MeV}$ at room temperature, a continuous nitride layer of the order of $1 \mu \mathrm{m}$ can be synthesized. There are, however, techniques exploring elevated temperatures of up to $600{ }^{\circ} \mathrm{C}$ or hybrids such as plasma immersion implantation or low voltage plasma immersion implantation, allowing generating thicker layers [15]. A comparative test with the beam ion implantation, plasma ion implantation, ion nitriding and gas nitriding of AISI 304 stainless steel created the same microstructure with nitrogen in iron solid solution [16]. After treatment, conducted at $400{ }^{\circ} \mathrm{C}$ for $0.5 \mathrm{~h}$ and $1 \mathrm{~h}$, both the beam ion implantation and the plasma ion implantation produced over $1 \mu \mathrm{m}$ thick layer, enriched in nitrogen to 20-30 at $\%$, while ion nitriding and gas nitriding produced layers with a thickness below $1 \mu \mathrm{m}$ and the lower nitrogen concentration.

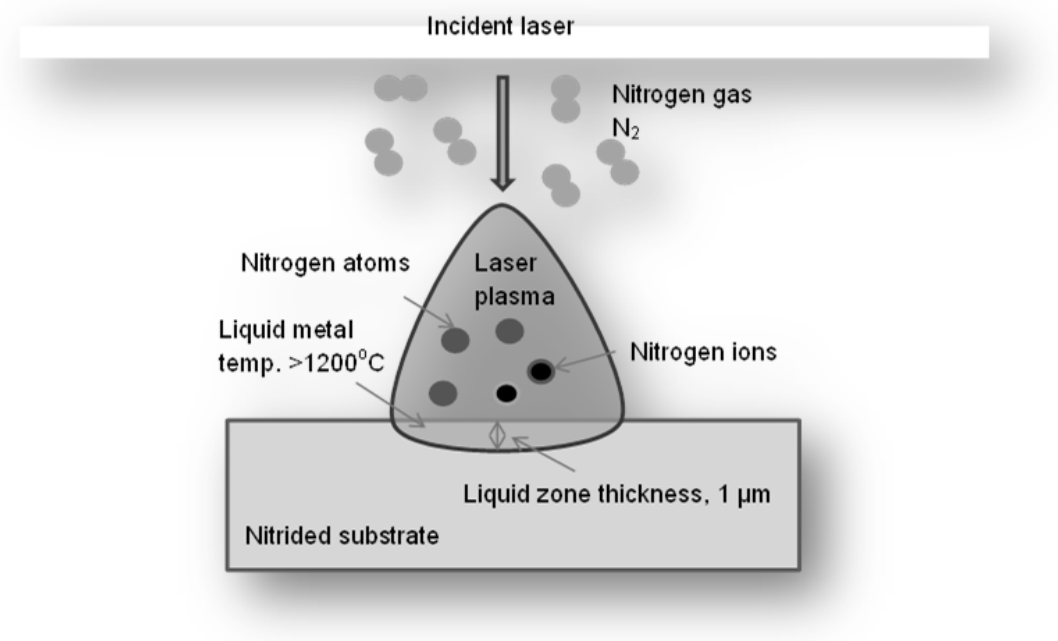

Figure 6. Principles of laser nitriding

\subsection{Process theory}

The Fe-N phase diagram provides essentials for nitriding of iron and low carbon steels. It consists of several solid solutions of $\mathrm{N}$ in $\alpha$-Fe and $\gamma$-Fe, stable chemical compounds ( $\gamma^{\prime}-$ $\left.\mathrm{Fe}_{4} \mathrm{~N}_{1-z}, \zeta-\mathrm{Fe}_{2} \mathrm{~N}\right)$ and metastable phases $\left(\alpha^{\prime}-\right.$ martensite, $\left.\alpha^{\prime \prime}-\mathrm{Fe}_{16} \mathrm{~N}_{2}\right)$ [17]. The bcc lattice of $\alpha$-Fe can dissolve up to 0.4 at $\%$ of $\mathrm{N}$ without substantial straining with nitrogen atoms occupying octahedral interstices in a random matter. After the content of nitrogen dissolved in pure iron exceeds 2.4 at $\%$, the $\gamma^{\prime}$ nitrogen martensite with a structure similar to the carbon martensite, is formed. At that nitrogen level, the bcc lattice experiences tetragonal straining and nitrogen atoms occupy $1 / 3$ of the possible octahedral interstices [18] [19]. The nitrogen austenite phase can dissolve up to 10.3 at $\%$ of nitrogen and its atoms are randomly located in octahedral interstices of the fcc Fe lattice. It is considered that the Fe-N solid solution can be conceived as composed of two interpenetrating lattices: the sublattice for Fe-atoms and 
the sublattice for $\mathrm{N}$ atoms [20]. When sites in Fe sublattice can be considered as fully occupied, sites in $\mathrm{N}$ sublattice, which constitutes of octahedral interstices of the $\mathrm{Fe}$ sublattice, are partly occupied by $\mathrm{N}$ atoms and partly by vacancies. The $\gamma^{\prime}-\mathrm{Fe}_{4} \mathrm{~N}_{1-z}$ nitride has a cubic elementary cell, formed by an fcc sub-lattice of Fe atoms with ordered arrangement of nitrogen atoms in central octahedral interstices. It has a narrow range of homogeneity within $19.3-20$ at $\%$ at $590{ }^{\circ} \mathrm{C}$. A schematic of the crystal structure of $\gamma^{\prime}$-Fe4 $\mathrm{N}$ where nitrogen atoms occupy a quarter of the octahedral sites, surrounded by the shadowed octahedral, is shown in Fig. 7a [21]. On the other hand, the $\varepsilon$ nitride has a variable stoichiometry of $\varepsilon-\mathrm{Fe}_{2} \mathrm{~N}_{1-z}$ with a structure based on $\mathrm{fcc} F e$, in which nitrogen atoms stay in octahedral sites and form a diamond type sub-lattice. The $\varepsilon$ nitride has the largest range of homogeneity in Fe-N system, reaching from 15 to 33 at\% of nitrogen. For some materials, not typical precipitation may occur; nitriding of Fe 2 at\% Si alloy led to silicon nitride precipitates formed inside the ferrite grains and along grain boundaries [22]. The precipitates were amorphous with a stoichiometry of $\mathrm{Si}_{3} \mathrm{~N}_{4}$. The amorphous nature is explained by thermodynamics due to the fact that the precipitation process occurred very slowly due to the very large volume misfit between the nitride and matrix.

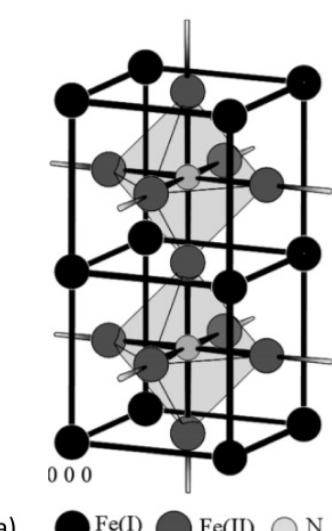

(a)

$\mathrm{Fe}(\mathrm{I})$

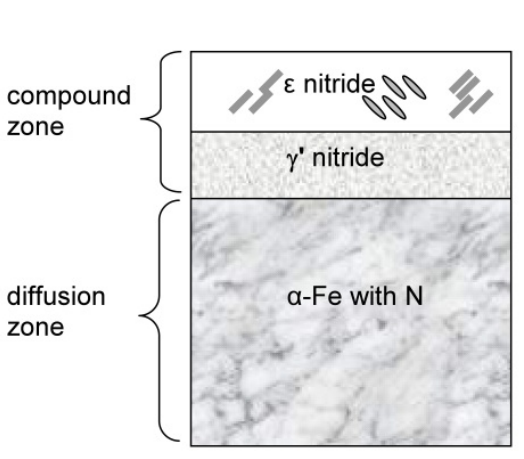

(b)

Figure 7. Schematics of: (a) crystal structure of $\gamma^{\prime}-\mathrm{Fe}_{4} \mathrm{~N}$ showing two unit cells [21]; (b) phase distribution within a nitrided case on steel and accompanied nitrogen depth concentration.

During nitriding, a compound layer, composed of iron nitrides $\varepsilon$ and/or $\gamma^{\prime}$, is formed at the steel surface. Beneath the compound layer a diffusion zone extends in the ferrite matrix in which nitrogen is dissolved interstitially. The heat effect of slow cooling after nitriding or the separate heating cycle lead to formation of the $\gamma^{\prime}-\mathrm{Fe}_{4} \mathrm{~N}_{1-z}$ nitride which, in turn, increases the nitrogen content in the $\varepsilon-\mathrm{Fe}_{2} \mathrm{~N}_{1-z}$ nitride. Morphologically that process can change a ratio between sub-layer thicknesses within the compound layer at the expense of $\varepsilon$-Fe $\mathrm{N}_{1-z}$ or cause a precipitation of $\gamma^{\prime}-\mathrm{Fe}_{4} \mathrm{~N}_{1-z}$ phase within the $\varepsilon$-Fe2 $\mathrm{N}_{1-z}$ layer, as shown in Fig. $7 \mathrm{~b}$. The particular depth structure of nitrided layer depends on the substrate chemistry and nitriding process, and examples for liquid, gas and plasma technologies are shown in Fig. 8. 

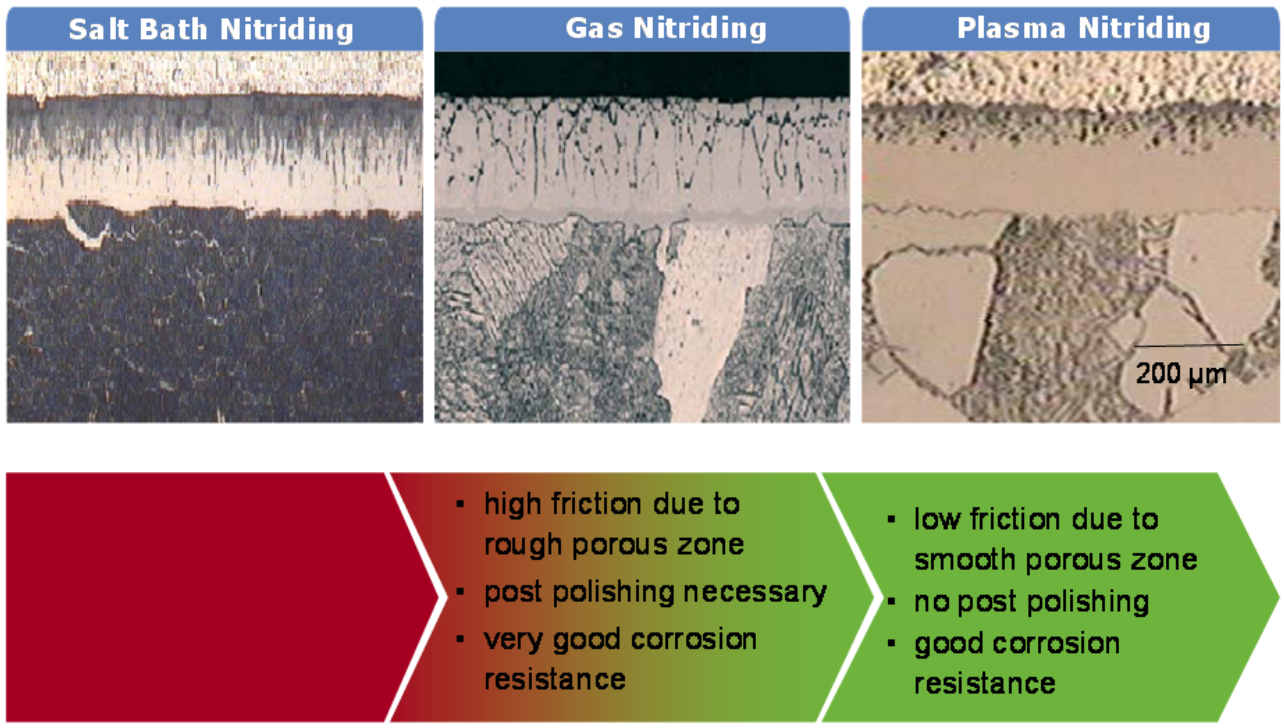

Figure 8. Microstructures of steel after liquid salt, gas and plasma nitriding along with some characteristic features aligned in a direction of improvement (with permission from Rubig $\mathrm{GmbH}$ )

\subsection{Nitrided layer and its effect on substrate properties}

Nitriding changes primarily the surface related properties. However, the presence of nitrided case affects also properties of the material volume beneath the nitrided case and the entire component.

\subsubsection{Nitrided case depth}

The quality control after nitriding is performed by (i) measuring the superficial hardness and its depth profile (ii) determining the nitrided case depth and (iii) an assessment of the cross-sectional microstructure. To provide unambiguous specifications on engineering drawings, two terms of nitrided case depths were introduced [23]. The total case depth, sometimes called simply as the case depth, is defined as the dark-etching sub-surface zone as determined metallographically on the component cross section. For alloys, which do not easily respond to etching or do not exhibit the sharp transition between the base material and diffusion zone, the total case depth is defined as a depth below the surface at which the microhardness is $10 \%$ higher than that of the base steel beneath it. The effective case depth is defined as the case depth where hardness exceeds certain values, defined either by the engineering drawing or standard. For typical nitriding steels, that hardness level is $50 \mathrm{HRC}$ as converted from microhardness, which can be directly measured on the cross section [23]. As seen in Fig. 9, for the particular nitrided case there may be substantial differences between the effective and total case depths. 


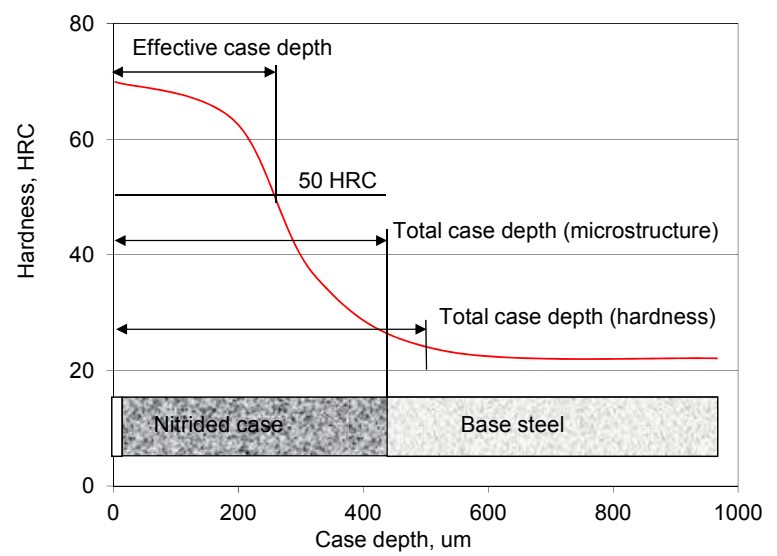

Figure 9. Schematics explaining measurements of total and effective case depths after nitriding

\subsubsection{Role of compound zone}

Within the nitrided case, the compound layer thickness and its integrity are of primary importance for component service performance. Due to its chemical stability the compound layer improves the corrosion resistance. In case of high nitrogen concentration the compound layer may be excessively porous and brittle so often it may also peel from the substrate increasing scuffing. After peeling, it may cause damage to tightly fit wear couples or contamination to processed products. Thus, it may be undesirable. Of specific applications, the compound layer is detrimental to gear life, particularly when gears experience misalignment during service [24]. Therefore, depending on nitriding class, certain thickness of compound layer is permitted [23]. For example, aerospace applications have strict restrictions where only trace amount of the compound zone, below $2 \mu \mathrm{m}$, is acceptable [25]. In some applications its presence is not permitted at all. Two examples of nitrided steels without the compound layer are shown in Fig. 10.
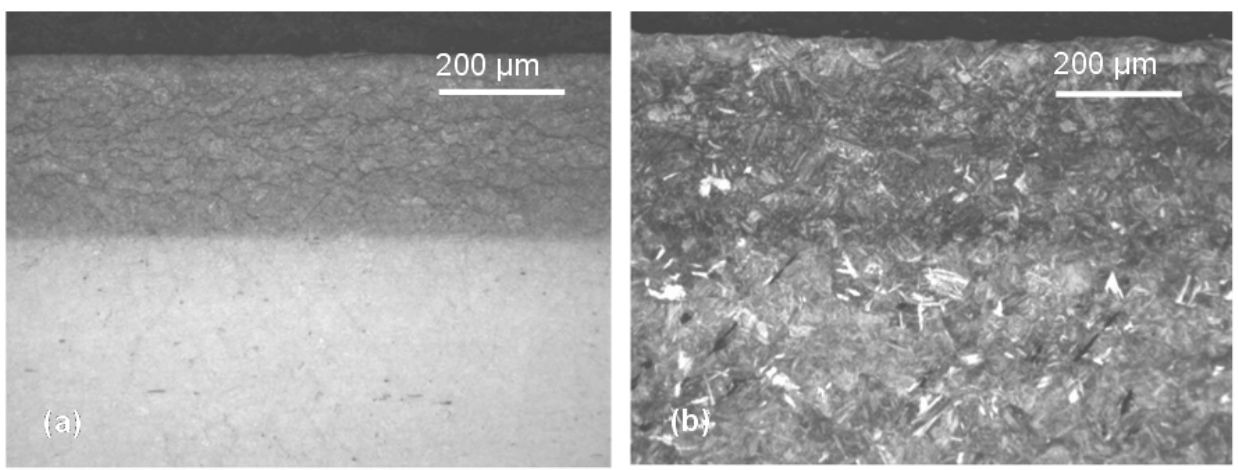

Figure 10. Microstructure of nitrided case on steel with absent or negligible compound layer: (a) finegrained steel with a clear interface with the base steel; (b) coarse-grained steel with no clear interface with the base steel 
Although a thickness of the compound zone depends on substrate chemistry, the essential control of compound layer formation is through altering the process parameters. In gas nitriding, the two-stage process, as developed by Carl Floe in 1953, is used to minimize the compound zone thickness [26]. The first stage ensures the rapid formation of the compound layer and the second stage arrests a formation of the compound layer without allowing the diffusion zone to be de-nitrided. The first stage runs with ammonia gas at a dissociation rate of about $30 \%$ at $495{ }^{\circ} \mathrm{C}$, followed by increasing temperature to $563{ }^{\circ} \mathrm{C}$ and the dissociation rate to $75-85 \%$. For plasma nitriding, the role of chamber atmosphere in the compound layer formation is critical as detailed in Table 1 . The post nitriding removal of the compound layer is costly and requires lapping, honing, grinding or polishing. Since mechanical methods introduce stress, subsequent stress relieving may be necessary. Another alternative of the compound layer removal is by chemical etching in cyanide solutions.

It is known that small additions of oxidizing species to plasma or gas nitriding have a beneficial effect on nitrided layer formation since the presence of oxygen increases the layer growth rate and stabilizes the $\varepsilon$-compound layer [27]. When applying a post-oxidation step after nitriding the cohesive, homogeneous layer of iron oxide grows which further improves the corrosion resistance (Fig. 11) [28]. When the oxide layer is essential for plain carbon steels it is also important for Cr-containing stainless steels. An unalloyed steel with 1-2 $\mu \mathrm{m}$ thick oxide layer exhibits a wide range of passivation by the corrosion current and high breakdown potential. The effect of the oxide layer on the $\varepsilon$-compound layer is often compared to the effect of $\mathrm{CrO}_{2}$ passivation film on a surface of stainless steel.

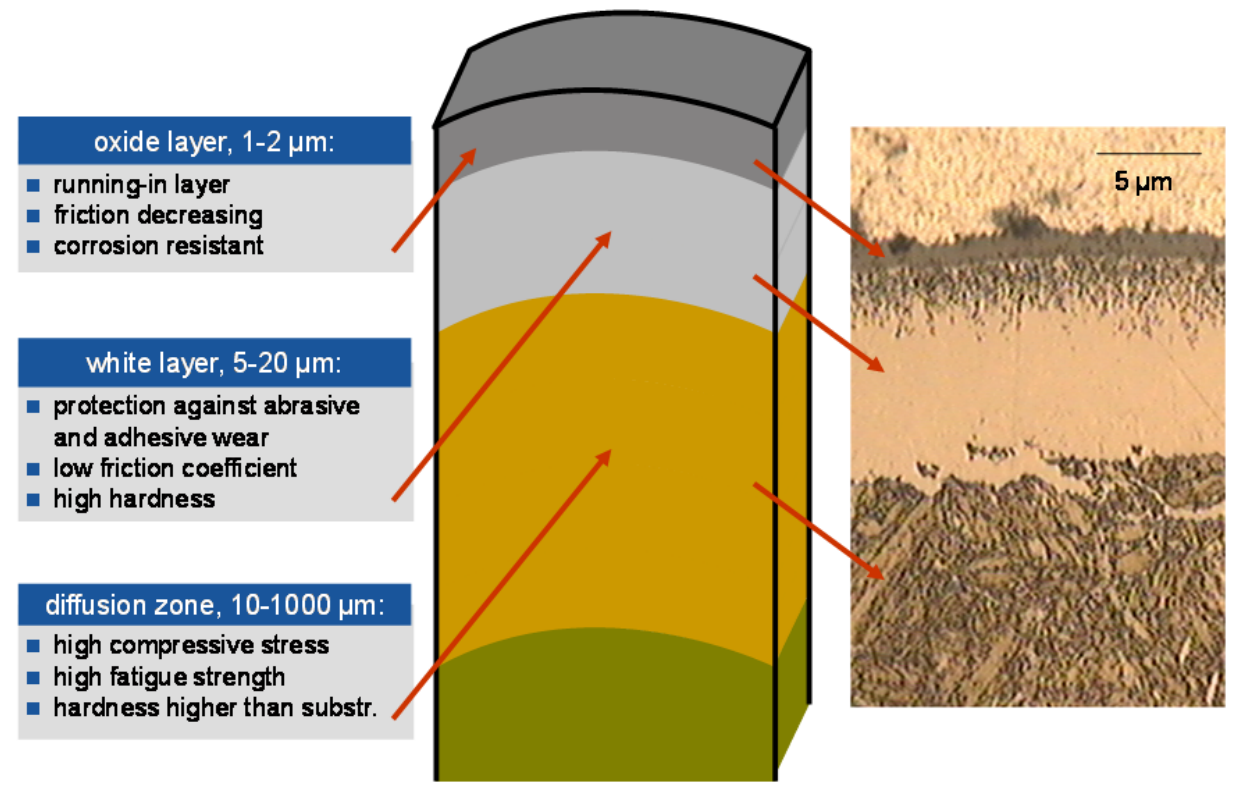

Figure 11. Microstructure after Plusox ${ }^{\mathrm{TM}}$ nitriding with major functional zones and their performance characteristics (with permission from Rubig $\mathrm{GmbH}$ ) 


\begin{tabular}{llll}
\hline Compound layer & $\mathrm{N}_{2}(\%)$ & $\mathrm{H}_{2}(\%)$ & $\mathrm{CH}_{4}(\%)$ \\
\hline Negligible & $8-15$ & $85-92$ & - \\
Thin, continuous & $20-35$ & $65-80$ & - \\
Thick, continuous & $40-60$ & $40-60$ & - \\
\hline \hline Extra thick & $75-79$ & $11-25$ & $1-2$ \\
\hline
\end{tabular}

Source: Rubig $\mathrm{GmbH}$

Table 1. Compound layer control during plasma nitriding

\subsubsection{Dimensional changes}

Although dimensional changes during nitriding are relatively small, they are definitely measureable. Therefore for precision parts, the dimensional change must be considered during the manufacturing process to compensate the nitriding related increase (Fig. 12a).

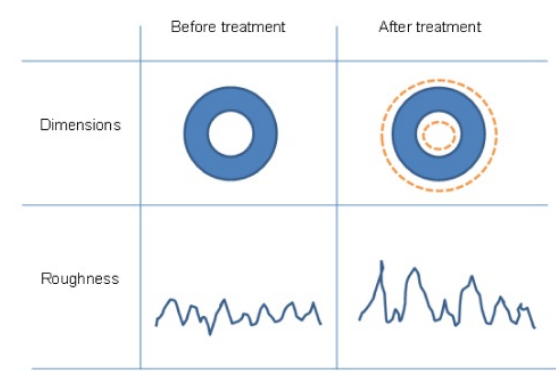

(a)

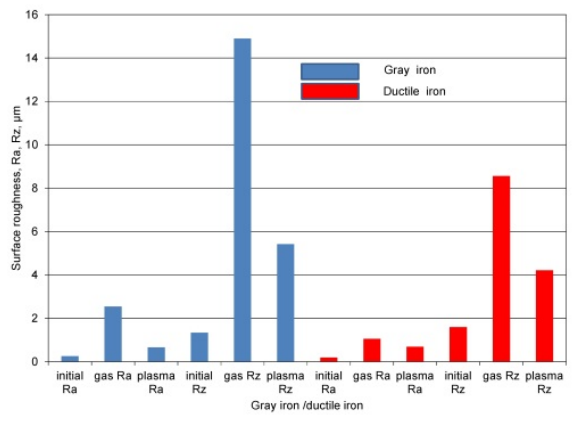

(b)

Figure 12. Schematics emphasizing changes of dimensions and surface roughness after nitriding (a) and influence of gas and plasma nitriding on roughness parameters of grey and ductile cast irons $(b-$ based on data from [30] [29])

The volume increase depends on the quantity of the absorbed nitrogen. In some cases, changes related to incorporated nitrogen are superimposed on structural transformations taking place within steel at nitriding temperatures. For the hardened and inadequately tempered steel, a decomposition of still existing austenite can increase a proportion of the volume change. In case of martensitic age-hardened steels, some shrinkage takes place and reduces the overall dimensional changes. In addition, there are also changes in surface topography. As a result of nitrogen absorption an increase in surface roughness occurs. As shown for the case of nitriding-nitrocarburizing, surface roughening depends on the process type and substrate material. In the case of grey and ductile cast irons, the former was especially sensitive to surface roughening with 10 times increase of roughness parameters (Fig. 12b). Moreover, plasma process produced generally much smoother surfaces as compared to the gas process [29] [30]. Thus, to bring the roughness to its initial value, post- 
nitriding polishing may be required. Also, stress from previous mechanical or thermal treatment may lead to part distortion during nitriding. To provide the stress-free component, prior to nitriding the stress relief should be conducted at temperature at least 50 ${ }^{\circ} \mathrm{C}$ higher than the nitriding process.

\subsubsection{Fatigue life and internal stress}

In general, nitriding improves the characteristics of high cycle fatigue. The increase in high cycle fatigue strength is caused by a formation of the strong nitrided layer and a generation of compressive macro-stress. During failure, the initiation of cracks occurs at the interface between the nitrided layer and the matrix. For low cycle fatigue the decrease in durability was recorded due to cracking of the stronger nitrided layer at high stress loadings of repeated nature [31]. Two different behaviours during fatigue tests with smooth and notched samples were distinguished. For nitrided samples with a notch, acting as stress riser, faster crack initiation was recorded. No direct correlation was identified between the hardness and internal macro-stress. Moreover, an increase in fatigue life is not always correlated with the nitrided case thickness. Other factors, such as the nitrided layer structure and steel composition exert effect as well. According to Ericsson [32], the contributing factors of stresses generation during nitriding are different thermal expansion coefficients for the phases present, growth and precipitation stresses for nitrides as well as stresses due to the nitrogen composition gradient. In addition, the thermal stress may also be involved. There are results obtained by the conventional tilt and grazing incidence $\mathrm{X}$-ray diffraction methods, that the residual stress in the compound layer is of tensile nature and changes with depth within the first $2 \mu \mathrm{m}$ of the $10 \mu \mathrm{m}$ thick compound layer [33]. The constant nitrogen concentration within the first $2 \mu \mathrm{m}$ thickness of the surface layer does not support the concentration gradient in stress generation cause as claimed above.

\subsection{Steels applicable to nitriding}

In general, nitriding is applicable to a wide variety of carbon steels, low alloy steels, tool steels, stainless steels and cast irons. For optimum properties after nitriding, however, there are steels with chemistries, particularly designed for this purpose. They contain strong nitride-forming elements such as $\mathrm{Al}, \mathrm{Cr}, \mathrm{Mn}, \mathrm{Mo}$ and $\mathrm{V}$. There is a limitation on carbon content which should not exceed $0.5 \%$, as most nitride-forming elements also form stable carbides which limit binding of nitrogen. When differences in hardness depth profiles for carbon and alloyed steels are essential (Fig. 13a), there are also substantial differences between individual grades, designed for nitriding (Fig. 13b). The especially high surface hardening is achieved with steels containing $\mathrm{Al}$, forming $\mathrm{AlN}$ nitrides. However, additions of $\mathrm{Al}$, typically in the range of $1 \%$, cause steel brittleness. The nickel nitriding steels containing aluminum develop higher core strengths than do nickel-free nitriding grades. Nickel also increases the toughness of the nitrided case [34]. The base steel properties are of importance to provide the support for nitrided case, especially in applications where components carry high compressive and bending stresses. A selection of steels designed for nitriding is listed in Table 2. 

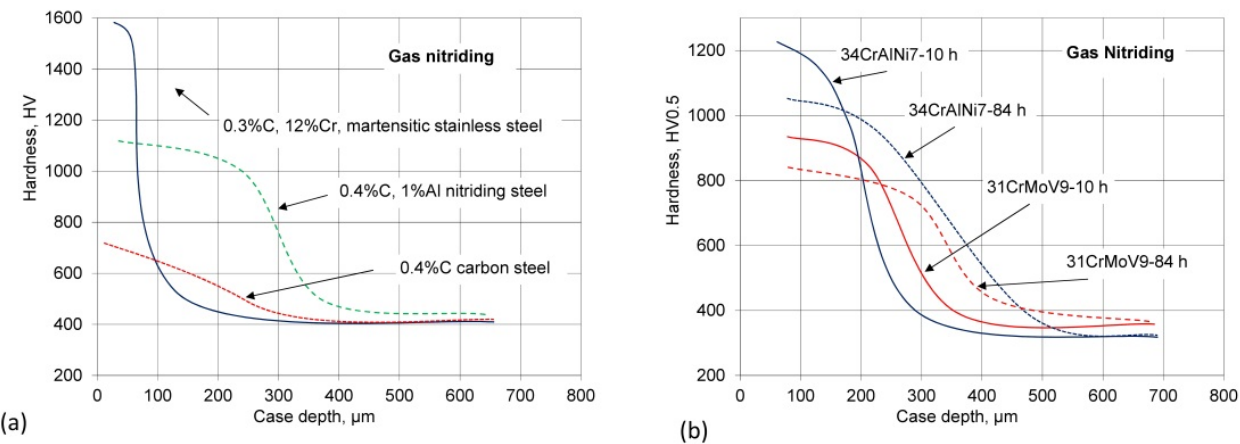

Figure 13. Effect of the steel composition on hardness depth profiles after nitriding: (a) comparison between carbon and alloyed grades; (b) comparison between two nitriding grades \{ (b) based on [41] with permission from Schmolz + Bickenbach \}

The deep nitrided steel, 32CrMoV13, has an application for aerospace bearings of main shafts or jet engines, operating under high speed, high temperature and limited lubrication. This application requires the typical nitrided case of more than $600 \mu \mathrm{m}$, achieved after gas process in the temperature range of $525-550{ }^{\circ} \mathrm{C}$ for up to $100 \mathrm{~h}$ [35]. For that case depth, the surface hardness ranges from 730 to $830 \mathrm{HV} 30$. The compound layer of approximately 30 $\mu \mathrm{m}$ thick is removed by grinding from rolling races and working surfaces. Within the diffusion layer, two zones may be distinguished. First is the $100 \mu \mathrm{m}$ thick zone, adjacent to the compound layer, depleted of carbides, likely due to their dissolution and precipitation more stable nitrides or carbonitrides. The second zone, adjacent to the base steel, is precipitates free. It is considered that the good service performance of nitrided layer and its superior rolling-contact properties are achieved due to semi-coherent precipitates of nanosize nitrides and high compressive residual stresses. An example of Al-free steel with $\mathrm{V}$ used for camshafts is OvaX200 steel [36]. After $20 \mathrm{~h}$ of gas nitriding at $490-510{ }^{\circ} \mathrm{C}$, The OvaX200 steel reaches the surface hardness of 850 HV1000.

The key concern during nitriding of stainless steels is to retain their corrosion resistance. The low temperature nitriding of austenitic grades leads leads to formation of nitrogen expanded austenite. This so-called S-phase exhibits an increased hardness and wear resistance combined with excellent corrosion resistance, inherent for stainless steel [37]. It is claimed that the active-screen plasma nitriding brings some benefits to nitriding of stainless steel. According to that mechanism, the material sputtered from the active screen and redeposited on the nitrided surface plays an important role in the nitriding process. Namely, the sputtered atoms react with nitrogen containing species in the plasma and deposit on the steel surface. Then, the deposited iron nitrides decompose, releasing nitrogen which, in turn, diffuses into the sub-surface layer [38].

Nitriding is also applicable to maraging steels which have very low carbon content, typically below $0.03 \%$, and are strengthened by the precipitation of intermetallic compounds, taking place at a temperature of approximately $480{ }^{\circ} \mathrm{C}$. The purpose of nitriding the maraging 
steels is to increase their wear resistance. Since the temperature of conventional gas nitriding exceeds the aging temperatures of maraging steels, the plasma nitriding is more suitable. The plasma nitriding at a temperature as low as $450{ }^{\circ} \mathrm{C}$ for $10 \mathrm{~h}$, in case of the Fe- $18 \mathrm{Ni}-8.8 \mathrm{Co}-$ $5 \mathrm{Mo}-0.4 \mathrm{Ti}-0.1 \mathrm{Al}$ steel, generates the nitrided layer with a thickness of $120 \mu \mathrm{m}$ and surface hardness of $800 \mathrm{HV}$ [39]. At the same time, it does not cause structural changes in the substrate, thus preserving the original microstructure.

The plasma nitriding with its surface sputtering effect, removing the surface oxide layer, is suitable for nitriding of high entropy alloys, containing large volumes of oxide-forming elements, such as $\mathrm{Al}, \mathrm{Cr}, \mathrm{Si}$ and $\mathrm{Ti}$ [3]. For the particular composition of $\mathrm{Al}_{0.3 \mathrm{CrFe}} \mathrm{Cr}_{5} \mathrm{MnNi} 0.5 \mathrm{a}$ dual-phase structure of fcc and bcc develops after homogenisation at $1100{ }^{\circ} \mathrm{C}$ [40]. After plasma nitriding at $525^{\circ} \mathrm{C}$ for $45 \mathrm{~h}$, the $80 \mu \mathrm{m}$ thick layer, with a peak hardness of $1300 \mathrm{HV}$, is generated. Both the bcc and fcc phases experience uniform nitriding and main nitrides are $\mathrm{AlN}, \mathrm{CrN}$ and $(\mathrm{Mn}, \mathrm{Fe}){ }_{4} \mathrm{~N}$. The alloy reaches the wear resistance 49-80 times higher than the nitrided conventional steels.

\begin{tabular}{|c|c|c|c|c|c|c|c|c|}
\hline Steel & C & $\mathrm{Mn}$ & $\mathrm{Si}$ & $\mathrm{Cr}$ & Mo & $\mathrm{Ni}$ & $\mathrm{V}$ & $\mathrm{Al}$ \\
\hline $\begin{array}{l}\text { Nitralloy } 135 \mathrm{M} \\
\text { AMS } 6470\end{array}$ & $0.38-0.45$ & ; $0.5-0.8$ & $0.2-0.4$ & $1.4-1.8$ & $0.35-0.45$ & - & - & $0.85-1.2$ \\
\hline Nitralloy G & 0.35 & 0.55 & 0.3 & 1.2 & 0.2 & - & & 1.0 \\
\hline $\begin{array}{l}\text { Nitralloy N } \\
\text { AMS } 6475\end{array}$ & $0.2-0.26$ & $0.5-0.7$ & $0.2-0.4$ & $1.0-1.25$ & $0.2-.3$ & $3.25-3.75$ & - & $1.1-1.4$ \\
\hline Nitralloy EZ & 0.35 & 0.8 & 0.3 & 1.25 & 0.2 & $0.2 \mathrm{Sc}$ & - & 1.0 \\
\hline $\begin{array}{l}\text { 34CrAlNi7 } \\
\text { DIN } 1.8550\end{array}$ & $0.30-0.37$ & $0.4-0.7$ & $\leq 0.4$ & $1.0-1.3$ & $0.15-0.25$ & - & - & $0.8-1.2$ \\
\hline $\begin{array}{l}\text { 41CrAlMo7 } \\
\text { DIN } 1.8509\end{array}$ & $0.38-0.45$ & $0.4-0.7$ & $\leq 0.4$ & 1.5.1.8 & $0.2-0.35$ & - & - & $0.8-1.2$ \\
\hline $\begin{array}{l}\text { 34CrAlMo5 } \\
\text { DIN } 1.8507\end{array}$ & $0.30-0.37$ & $0.4-0.7$ & $\leq 0.4$ & $1.5-1.8$ & $0.15-0.25$ & $0.85-1.15$ & - & $0.8-1.2$ \\
\hline $\begin{array}{l}\text { 15CrMoV5-9 } \\
\text { DIN } 1.8521\end{array}$ & $0.13-0.18$ & 0.8-1.1 & $\leq 0.4$ & $1.2-1.5$ & $0.8-1.1$ & - & $0.2-0.3$ & - \\
\hline $\begin{array}{l}\text { 31CrMoV9 } \\
\text { DIN } 1.8519\end{array}$ & $0.27-0.34$ & $0.4-0.7$ & $\leq 0.4$ & 2.3-2.7 & $0.15-0.25$ & - & $0.1-0.2$ & - \\
\hline $\begin{array}{l}\text { 31CrMo12 } \\
\text { DIN } 1.8515\end{array}$ & $0.28-0.35$ & $0.4-0.7$ & $\leq 0.4$ & $2.8-3.3$ & $0.3-0.5$ & - & - & - \\
\hline $\begin{array}{l}\text { 32CrMoV13 } \\
\text { AMS6481 }\end{array}$ & $.29-0.36$ & $0.4-0.7$ & $0.1-0.4$ & $2.8-3.3$ & $0.7-1.2$ & - & $0.15-0.35$ & - \\
\hline OvaX200 & $0.14-0.17$ & $1.2-1.4$ & 0.15 & $2.1-2.3$ & $0.45-0.55$ & $0.45-0.55$ & $0.15-0.25$ & - \\
\hline $5 \mathrm{Ni}-2 \mathrm{Al}$ & $0.20-0.25$ & $0.25-0.45$ & & $0.4-0.6$ & $0.2-0.3$ & $4.75-5.25$ & $0.08-0.15$ & $1.8-2.2$ \\
\hline
\end{tabular}

Table 2. Selection of steels, designed for nitriding (weight \%) [41] [36] [34] [26] 


\subsection{Nitriding of titanium alloys}

The competitiveness of titanium alloys is due to their high strength to weight ratio, heat and corrosion resistance. At the same time, the low surface hardness and wear resistance along with poor high-temperature oxidation resistance are seen as their major disadvantages. Nitriding is one of many treatments aimed at improving their tribological characteristics.

\subsubsection{Nitriding techniques applicable to titanium}

In principle, all major nitriding techniques are applicable to titanium. A disadvantage of gas nitriding is the high temperature of $650-1000{ }^{\circ} \mathrm{C}$ required, long time of up to $100 \mathrm{~h}$ and reported fatigue life reduction. For Ti-6Al-4V alloy a typical compound layer of 2-15 $\mu \mathrm{m}$ forms with a surface hardness between 500 and $1800 \mathrm{HV}$ [42]. The plasma nitriding of titanium alloys is conducted at temperatures of $400-950{ }^{\circ} \mathrm{C}$ and substantially shorter time from 0.5 to $32 \mathrm{~h}$, generating a compound layer with a thickness of approximately $50 \mu \mathrm{m}$. A reduction in fatigue strength may be eliminated by lowering the nitriding temperature. The ion beam nitriding, using nitrogen at temperatures of $500-900{ }^{\circ} \mathrm{C}$ for up to $20 \mathrm{~h}$, produces $5-8$ $\mu \mathrm{m}$ thick compound layer with microhardness of $800-1200 \mathrm{HV}$ on Ti-6Al-4V alloy. Also laser nitriding is applicable to titanium but surface case has a tendency to cracking. An attempt was made to apply the diode laser gas nitriding technique to Ti6Al4V alloy, commonly used for rotors and blades of engines in power generation [43]. The laser surface melting of the substrate surface in a mixture of nitrogen and argon leads to an increase in surface hardness up to $1300 \mathrm{HV} 0.2$ although the outcome depends on process parameters.

\subsubsection{Microstructure development during nitriding}

The formation of the nitrided layer on titanium involves several reactions taking place at the gas/metal interface and within the metal. At the nitriding temperature, below the $\mathrm{Ti}$ polymorphic transformation, the $\alpha$-Ti phase exists. First, the nitrogen absorbed at the surface diffuses inward titanium, forming the interstitial solution of nitrogen in the hcp titanium phase $\alpha-\operatorname{Ti}(\mathrm{N})$ and building the nitrogen concentration gradient. After exceeding the solubility limit, the $\mathrm{Ti}_{2} \mathrm{~N}$ phase is formed. During further increase in the nitrogen concentration at the gas/metal interface, $\mathrm{TiN}$ is formed as specified below:

$$
\alpha-\mathrm{Ti} \rightarrow \alpha-\mathrm{Ti}(\mathrm{N}) \rightarrow \mathrm{Ti}_{2} \mathrm{~N} \rightarrow \mathrm{TiN}
$$

After slow cooling, the precipitation in the diffusion zone is possible. The simplified morphological schematic, emphasizing the growth sequence, is shown in Fig. 14.

\subsubsection{Nitriding of other refractory metals $(\mathrm{Zr}, \mathrm{Nb}, \mathrm{Mo}, \mathrm{W}, \mathrm{Ta})$}

Many refractory metal nitrides offer an attractive combination of high electrical conductivity and good corrosion resistance. For Mo- $0.5 \% \mathrm{Ti}$ and pure Mo alloys the inward diffusion of nitrogen is the rate controlling step. After gas nitriding at $1100{ }^{\circ} \mathrm{C}$ they reach a hardness of $1800 \mathrm{HV}$ and the surface layer consists of two regions with the outer layer composed of $\gamma$ - 
$\mathrm{Mo}_{2} \mathrm{~N}$ and the inner layer of $\beta-\mathrm{Mo}_{2} \mathrm{~N}$ [44]. In Ti containing alloys an internal nitrided layer is additionally formed with a hardness of $800 \mathrm{HV}$ which contains the fine $0.4 \mathrm{~nm}$ thick platelike, coherent particles of TiN.

Thickness

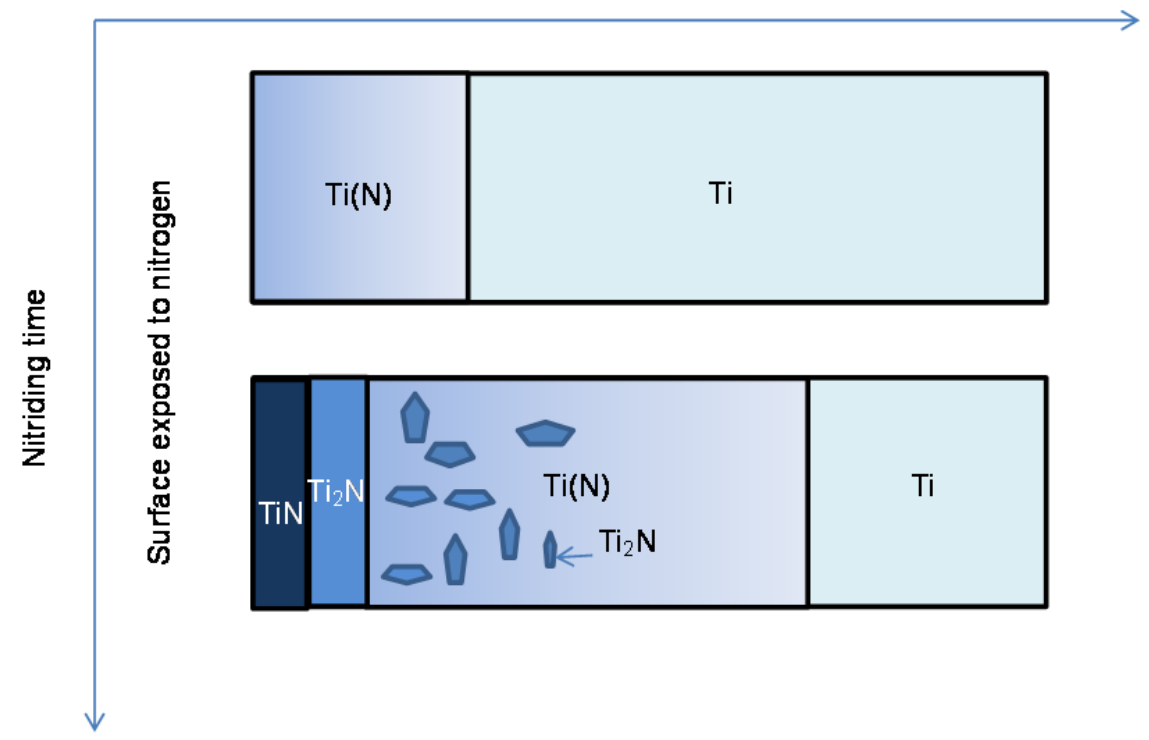

Figure 14. Schematics of the morphology development during nitriding of titanium

The nitrided niobium has a potential application in particle accelerators [6]. The niobiummade cavity of the superconducting radio-frequency accelerator operates at very low temperature of $1.9 \mathrm{~K}$ to achieve the sufficient performance. After nitriding of niobium, its surface is transformed to $\delta-\mathrm{NbN}$ with the critical temperature of $17 \mathrm{~K}$ as opposed to $9 \mathrm{~K}$ for pure $\mathrm{Nb}$. Such a change shows a promise to raise the accelerator operating temperature. The laser nitriding was found to be effective for niobium.

The refractory alloy composed of $\mathrm{Nb}, 30 \% \mathrm{Ti}$ and $20 \% \mathrm{~W}$, called Tribocor $532 \mathrm{~N}$, and produced by conventional melting techniques, benefits from nitriding as well [45]. Since titanium has the highest affinity to nitrogen of all elements in the alloy, TiN forms preferentially on the nitrided surface. During the next step, as the alloy becomes depleted in $\mathrm{Ti}$, the $\mathrm{Nb}$ nitride starts growing. As shown in Fig. 15, its surface microstructure changes completely. The nitrided surface achieves high hardness with superior corrosion resistance (Fig. 16). Among many applications, including an environment of molten magnesium and aluminum alloys [46], the nitrided $\mathrm{Nb}-30 \mathrm{Ti10W}$ alloy was considered in proton exchange membrane fuel cells for the bipolar plate. The plate serves to electrically connect the individual cells in a stack and to separate and distribute the reactant and product stream [5].

The nitrided zirconium has application potentials for cathodes in arc heaters, mainly due to its high erosion resistance under those service conditions [47]. After nitriding in a 
microwave plasma generator, the golden color zirconium nitride forms on its surface. In addition to metals, also ceramics of yttria-stabilized zirconia benefit from nitriding [48]. As a result of high temperature plasma nitriding, the complex layer, composed of tetragonal cubic zirconia, zirconium nitride and oxynitride, is created.
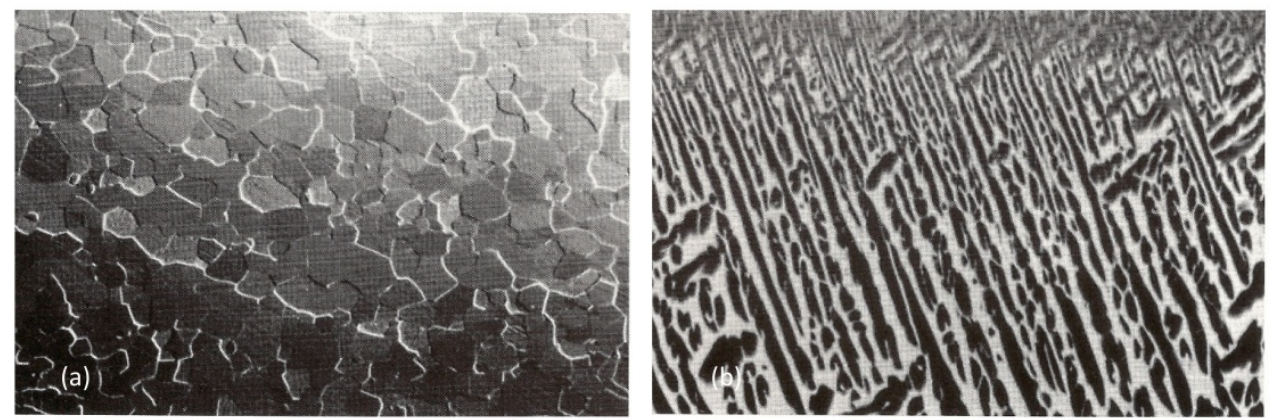

Figure 15. Microstructure of Tribocor $532 \mathrm{~N}$ alloy before and after nitriding. Approximate magnification 500x [45] (with permission from Elsevier Science)

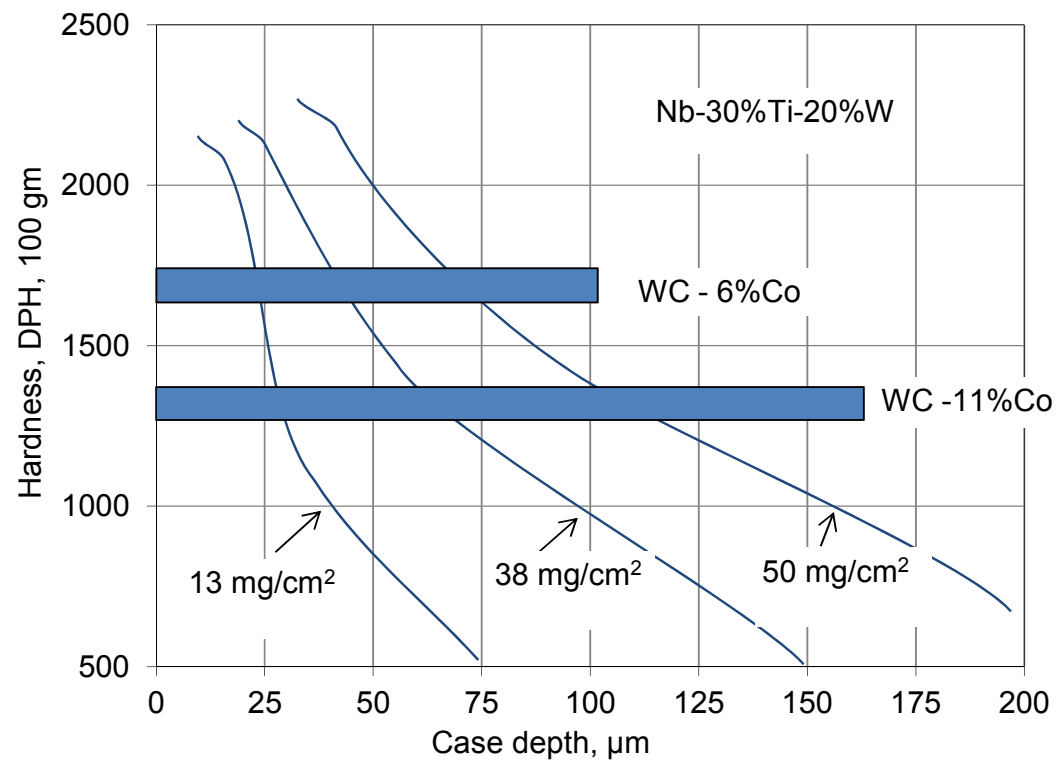

Figure 16. Hardness versus depth profile for three levels of nitrogen absorption in Tribocor $532 \mathrm{~N}$ alloy [45] (with permission from Elsevier Science)

\subsection{Nitriding of aluminum}

One of the key limitations in the application of aluminum alloys is their low wear resistance. Therefore, the purpose of aluminum nitriding is similar as in the case of titanium, i.e. to 
increase the surface wear resistance. At present, Al-Si alloys are used for wear applications or a hard surface layer must be created. The latter is most often achieved by $\mathrm{Al}_{2} \mathrm{O}_{3}$ alumina coatings.

The conventional plasma nitriding of aluminum alloys is conducted at temperature of 500 ${ }^{\circ} \mathrm{C}$ for $20 \mathrm{~h}$ to form $1-2 \mu \mathrm{m}$ thick layers. Since nitrogen is virtually insoluble in aluminum, during nitriding only the compound layer of AlN is formed. AlN is known for its high hardness of $1400 \mathrm{HV}$, high thermal conductivity and high electrical resistivity. In addition to nitriding, AlN can be formed on $\mathrm{Al}$ surface by several other techniques including evaporation or ball milling [49] [50]. The process of Al nitriding is slow since the diffusion of $\mathrm{N}$ in $\mathrm{Al}$ is the rate controlling step. To increase the nitriding rate, the grain size of $\mathrm{Al}$ should be refined. It suggests that the growth of AlN is controlled by grain boundary diffusion, hence increasing grain boundary density increases a number of fast diffusion paths. Another way of speeding up the AlN growth is by alloying additions and a presence of $1 \mathrm{wt} \%$ of $\mathrm{Ti}$ is effective. Under the same nitriding conditions of temperature $500^{\circ} \mathrm{C}$ and time of $20 \mathrm{~h}$ the 3 $\mu \mathrm{m}$ thick layer with co-precipitates of TiN grows as compared to 1-2 $\mu \mathrm{m}$ thick AlN in case of Ti absence [49].

An alternative technique used for $\mathrm{Al}$ nitriding is the electron beam excited plasma (EBEP) [51]. The technology is sustained by the electron impact ionization with an energetic electron beam being a source of low pressure plasma. When employing this method it is possible to create on AA5052 alloy after $45 \mathrm{~min}$ at $570{ }^{\circ} \mathrm{C}$ the AlN layer with a thickness of $5 \mu \mathrm{m}$ and pillar shape grains. At the interface with the substrate a spinel $\mathrm{MgAl}_{2} \mathrm{O}_{4}$ grows, affecting the adhesion of major AIN layer. Also inductively coupled RF plasma reactor is effective for nitriding of Al-Cu alloy 2011 [52]. At temperature of $400{ }^{\circ} \mathrm{C}$ the time of $36 \mathrm{~h}$ is needed to create a protective layer. During plasma nitriding of $\mathrm{Al}-\mathrm{Cu}$ alloys, $\mathrm{Al}_{2} \mathrm{Cu}$ precipitates increase the nucleation rate and growth of the nitrided case [53]. The crystallographic coherence between $\mathrm{AlN}$ and $\mathrm{Al}_{2} \mathrm{Cu}$ enhances the formation of $\mathrm{AlN}$ nodules and islands. The layer formation is also accelerated by the solid-state interaction between $\mathrm{Al}_{2} \mathrm{Cu}$ and penetrating nitrogen to form interfacial boundaries, acting as nitrogen diffusion paths. The plasma nitriding is relatively effective way to increase the corrosion resistance of aluminum. There are data pointing out that a treatment at $500{ }^{\circ} \mathrm{C}$ for $20 \mathrm{~h}$ leads to improvement during both the immersion test in $3.5 \% \mathrm{NaCl}$ and the polarization test [54].

In addition to an improvement in surface characteristics, the presence of AlN layer affects the bulk properties of aluminum. According to [55], the plasma nitriding of Al-Si-Mg alloy causes decrease in yield, ultimate tensile strength, elongation and stress relaxation rate. It was explained that stress created at the interface between the AlN and Al substrate contributed to the premature failure. Other failure contributors are argued to be defects created by diffusion of nitrogen into the lattice.

A deficiency of AlN films, formed by plasma nitriding, is their tendency to cracking and delamination due to large compressive stresses and the property difference between the AlN layer and the $\mathrm{Al}$ substrate. As a possible solution of increasing the AlN adhesion, a combination of barrel nitriding and plasma nitriding is proposed [4]. The barrel nitriding is 
performed as a pre-treatment before the plasma nitriding. In addition to $\mathrm{Al}_{2} \mathrm{O}_{3}$ and $\mathrm{Al}-$ $50 \mathrm{wt} \% \mathrm{Mg}$ powders, nitrogen gas is introduced and the content is heated to $630^{\circ} \mathrm{C}$.

\section{Nitrocarburizing (ferritic nitrocarburizing)}

During nitrocarburizing, nitrogen and carbon are supplied to the surface of steel in ferritic state at temperatures usually between 500 and $580{ }^{\circ} \mathrm{C}$. The general classification of thermochemical treatments involving nitrogen and/or carbon is shown in Fig.17. According to some terminology, the high temperature equivalent of ferritic nitrocarburizing is called as austenitic nitrocarburizing. There is also a term of ferritic carburizing, describing the carburizing process at temperatures of the ferritic state.

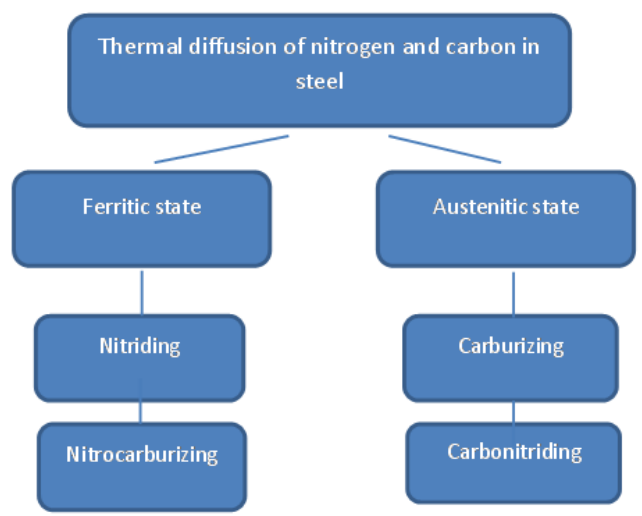

Figure 17. Classification of basic thermochemical treatments involving nitrogen and carbon

\subsection{Process technology}

The salt bath nitrocarburizing by Tufftride ${ }^{\circledR}$ is performed in a mixture of alkali cyanate and alkali carbonate in the temperature range of $480-630{ }^{\circ} \mathrm{C}$ [56]. The gas nitrocarburizing has been developed as a cleaner alternative to the salt bath technology. Besides ammonia, required to supply the nascent nitrogen, the nitrocarburizing atmospheres contain carbonbearing additives like exothermic and endothermic gases $\mathrm{CO}_{2}, \mathrm{CO}$ and $\mathrm{H}_{2}$ as products of the dissociation of methanol. There is also a hybrid treatment, integrating the low temperature plasma nitriding and additions of carburizing species to the plasma media to cause the simultaneous incorporation of nitrogen and carbon. However, using the glow discharge of plasma containing nitrogen and carbon species it is difficult to produce a single $\varepsilon-\mathrm{Fe}_{2-3}(\mathrm{~N}, \mathrm{C})$ phase compound layer on engineering steels [57]. Instead, the plasma nitrocarburizing generates a compound layer with mixed phases of $\varepsilon-\mathrm{Fe}_{2-3}(\mathrm{~N}, \mathrm{C})$ and $\gamma^{\prime}-\mathrm{Fe}_{4}(\mathrm{~N}, \mathrm{C})$, known to be detrimental in tribological applications, especially under impact loads. According to [58], excluding for low-carbon steel or to some extent for medium carbon unalloyed steel, gas nitrocarburizing does not produce compound or diffusion layers faster than gas nitriding. Moreover, the properties of nitrocarburized parts are not always superior to those obtained by nitriding and the nitrocarburizing process is more difficult to control. 
There is a substantial difference between gas and plasma nitrocarburizing when considering an environmental aspect. As shown in Table 3, in addition to drastic reduction of $\mathrm{CO}, \mathrm{CO}_{2}$ and $\mathrm{NO}_{\mathrm{x}}$ emission, reaching 500-5000 times by plasma technology, the total gas consumption is at least 10 times lower than in the gas process [57].

\begin{tabular}{l|lll|} 
Emissions & Unit & Plasma & Gas \\
\hline Amount of gas used & $\mathrm{m}^{3} / \mathrm{h}$ & 0.6 & 6.0 \\
Total carbon emission via CO/CO 2 & $\mathrm{mg} / \mathrm{m}^{3}$ & 504 & 137253 \\
Total amount of $\mathrm{NO}_{x}$ gas & $\mathrm{mg} / \mathrm{m}^{3}$ & 1.2 & 664 \\
Output of residual carbon bearing gas & $\mathrm{mg} / \mathrm{h}$ & 302 & 823518 \\
Output of residual NOx gas & $\mathrm{mg} / \mathrm{h}$ & 54 & 3984
\end{tabular}

Table 3. Emission data for plasma and gas nitrocarburizing [57]

Among different nitrocarburizing techniques, a special attention is paid to low pressure processes, performed in a mixture of $\mathrm{NH}_{3}$ and $\mathrm{CO}_{2}$. Since $\mathrm{CO}_{2}$ containing gas has a high oxygen potential, especially under low pressure conditions, oxygen atoms accelerate the formation of $\mathrm{Fe}_{3}(\mathrm{~N}, \mathrm{C})$ and contributes to the growth of adherent nitrocarburized layers [59]. The process named Nitreg-ONC ${ }^{\circledR}$ is based on Nitreg ${ }^{\circledR}$ technology but generates a modified complex compound layer which contains an increased concentration of carbon, oxygen and sulphur [60]. As a result, surface retains its high wear resistance, anti-scuffing and anti-seizing properties. Another advantage is the substantially increased corrosion resistance which for carbon steels reaches a level comparable with stainless grades. The increased corrosion resistance is associated with the superficial oxide structure which is not penetrable by corrosive fluids. In general, the treatment is considered a superior alternative to chrome plating.

\subsection{Surface layer structure}

During nitrocarburizing of iron, the microstructural evolution of the compound layer starts with the formation of carbon-rich cementite and develops into the direction of nitrogenricher and carbon-poorer phases of $\varepsilon$ and $\gamma^{\prime}$ [61]. Both steps are a consequence of higher solubility of nitrogen in $\alpha$-Fe than carbon and lower rate of nitrogen transfer from the gas into the solid phase. The compound layer is typically composed of carbonitrides of iron $\varepsilon$ $\mathrm{Fe}_{3}(\mathrm{~N}, \mathrm{C})_{1+x}$ and $\gamma^{\prime}-\mathrm{Fe}_{4}(\mathrm{~N}, \mathrm{C})_{1-z}$ along with $\theta$-Fe3 $\mathrm{C}$ cementite (Table 4) [62] [63]. As during nitriding, beneath the compound layer the diffusion zone forms with carbon and nitrogen being dissolved in the ferritic matrix. It is well documented that the best properties are achieved when the compound layer contains predominantly the single $\varepsilon$ phase (Fig. 18a). The compound layer, typically in the range of $20 \mu \mathrm{m}$, leads to significant improvements in hardness, wear and corrosion resistance. A presence of ammonia in gas nitrocarburizing atmosphere affects the compound layer structure and a presence of cementite $\mathrm{Fe}_{3} \mathrm{C}$. During ferritic carburizing of iron at a temperature of $550{ }^{\circ} \mathrm{C}$ in gas atmospheres containing a certain 
amount of $\mathrm{NH}_{3}$, massive layers of cementite $\mathrm{Fe}_{3} \mathrm{C}$ can be grown [64]. In order to generate thicker layers, the nitrocarburizing process is conducted at temperatures exceeding the Fe- $\mathrm{N}$ eutectoid point of $590{ }^{\circ} \mathrm{C}$. After austenitic plasma nitrocarburizing at $700{ }^{\circ} \mathrm{C}$ for $3 \mathrm{~h}$ of $0.45 \%$ $\mathrm{C}$ steel the layer contains mainly the $\varepsilon-\mathrm{Fe}_{2-3}(\mathrm{~N}, \mathrm{C})$ phase but unlike after ferritic nitrocarburizing process, the austenite layer forms between the $\varepsilon$ phase and diffusion zone (Fig. 18b) [57].
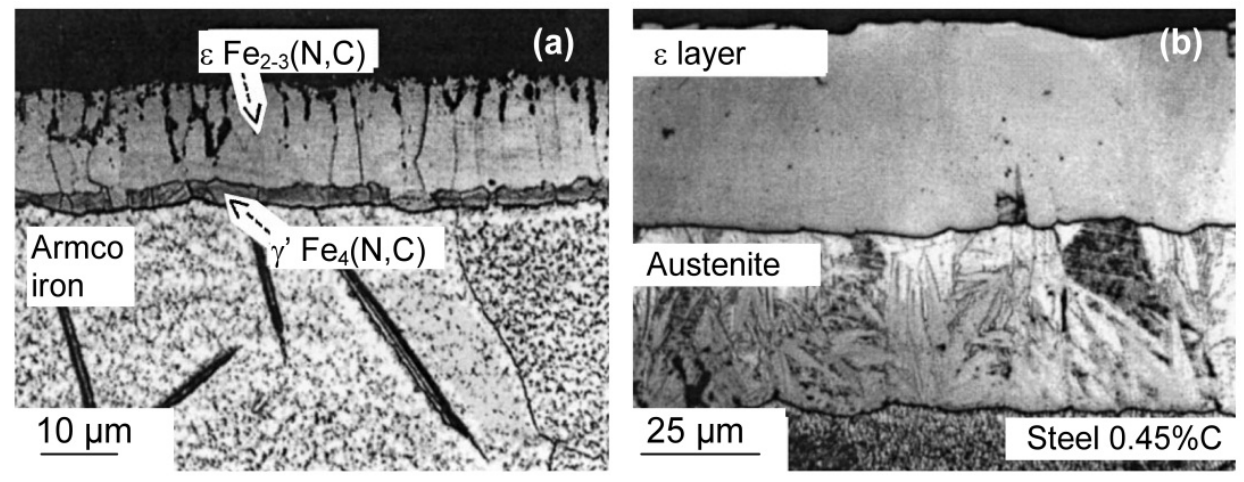

Figure 18. Microstructure differences after low temperature and high temperature plasma nitrocarburizing in atmosphere of $87 \% \mathrm{~N}_{2}+8 \% \mathrm{H}_{2}+5 \% \mathrm{CO}_{2}$ : (a) Armco iron, $570{ }^{\circ} \mathrm{C}$ for $3 \mathrm{~h}$; (b) $0.45 \% \mathrm{C}$ steel, $700^{\circ} \mathrm{C}$ for $3 \mathrm{~h}$ [57] (with permission from Elsevier Science)

There are benefits to surface corrosion resistance after combining the plasma nitrocarburizing and oxidizing [65]. The carbonitrided SKD61 steel with a $10 \mu \mathrm{m}$ thick compound layer (predominantly $\varepsilon-\mathrm{Fe}_{2}-3(\mathrm{~N}, \mathrm{C})$ and small proportions of $\gamma^{\prime}-\mathrm{Fe}_{4}(\mathrm{~N}, \mathrm{C})$ ) and $200 \mu \mathrm{m}$ thick diffusion layer subjected to plasma oxidation at $500{ }^{\circ} \mathrm{C}$ for $1 \mathrm{~h}$ creates $1-2 \mu \mathrm{m}$ thick magnetite $\mathrm{Fe}_{3} \mathrm{O}_{4}$ layer on top of the compound layer [66]. According to the anodic polarization test, a significant improvement in the steel corrosion resistance is achieved.

\begin{tabular}{|c|c|c|c|c|c|}
\hline Phase & $\mathrm{N}($ at. \%) & C (at. \%) & Crystallography & $\begin{array}{l}\text { Atom } \\
\text { arrangement }\end{array}$ & Reference \\
\hline$\alpha$-Fe & $0-37$ & $0-0.02$ & Fe bcc, & $\begin{array}{l}\mathrm{N}, \mathrm{C} \text { in } \\
\text { octahedral sites }\end{array}$ & [17] \\
\hline$\theta-\mathrm{Fe}_{3} \mathrm{C}$ & 0 & 25 & $\begin{array}{l}\text { Fe complicated } \\
\text { orthorhombic }\end{array}$ & $\begin{array}{l}\mathrm{C} \text { in bicapped } \\
\text { trigonal prisms }\end{array}$ & [64] [67] \\
\hline$\gamma^{\prime}-\mathrm{Fe}_{4} \mathrm{~N}_{1-\mathrm{z}}$ & $19.4-20$ & $<0.7$ & Fe fcc, & $\begin{array}{l}\mathrm{N} \text { ordered in } \\
\text { central } \\
\text { octahedral sites }\end{array}$ & [61] [68] [69] \\
\hline$\varepsilon-\mathrm{Fe}_{3}(\mathrm{~N}, \mathrm{C})_{1+\mathrm{x}}$ & $15-33$ & $0-8$ & Fe hcp, & $\begin{array}{l}\mathrm{N} \text { ordered in } \\
\text { octahedral sites }\end{array}$ & [61] [68] [69] \\
\hline
\end{tabular}

Table 4. Characteristics of phases in Fe-N-C system at $580-590{ }^{\circ} \mathrm{C}$ 


\subsection{Applications}

In addition to application of nitrocarburizing to carbon and nitriding steels to increase their surface hardness and tribological performance it is also used to stainless steels and special alloys. After low-temperature plasma nitrocarburizing at $450{ }^{\circ} \mathrm{C}$ of austenitic stainless steel AISI 304, the dual layer structure grows with a nitrogen-enriched layer on top of a carbon enriched layer. Both layers are free of nitride and carbide precipitates [70]. In addition to increased surface hardness up to $1500 \mathrm{HV}$ and improved wear resistance, the corrosion resistance is also positively altered. There is a difference in corrosion resistance between processes conducted at various temperatures below $450{ }^{\circ} \mathrm{C}$. When treatments conducted at $380^{\circ} \mathrm{C}$ and $415^{\circ} \mathrm{C}$ lead to similar properties, increasing temperature to $430{ }^{\circ} \mathrm{C}$ causes slightly higher corrosion resistance. The latter is attributed to the formation of a small amount of chromium nitride in the nitrogen-enriched surface layer. The overall improvement in corrosion resistance after nitrocarburizing of AISI 304 stainless steel is thought to be due to the extremely large supersaturation of an upper part of the nitrogen-enriched layer with both nitrogen and carbon. Also sintered Astaloy $\mathrm{CrM} ®+0.3 \% \mathrm{C}$, nitrocarburized in a salt bath at $580{ }^{\circ} \mathrm{C}$ for at least $2 \mathrm{~h}$, experiences an increased corrosion resistance [71]. Its surface layer after the treatment is dominated by the $\varepsilon$-iron carbonitride $\mathrm{Fe}_{2-3}(\mathrm{CN})$.

\section{Carburizing}

The objective of carburizing is to enrich surface layers of steel or other alloys with carbon. To achieve the sufficient carbon solubility and penetration depth the treatment is carried out at relatively high temperatures of $900-950{ }^{\circ} \mathrm{C}$. As a result, steels, which do not have the sufficient carbon content within their volume, obtain the hard surface. The reduced carbon content is deliberately selected to retain the core toughness.

The endothermic carburizing atmospheres consist of a mixture of carburizing ingredients such as $\mathrm{CO}$ and $\mathrm{CH}_{4}$ and decarburizing ones such as $\mathrm{CO}_{2}$ and $\mathrm{H}_{2} \mathrm{O}$. To control the process, the carburizing potential of the furnace atmosphere requires the measurement of all the gas constituents $\mathrm{CO}, \mathrm{CO}_{2}, \mathrm{CH}_{4}$ and $\mathrm{H}_{2} \mathrm{O}$. The driving force for carburizing is determined by the gradient between potentials of carbon in the furnace atmosphere and carbon at the steel surface. The key reactions of carburizing involve [72]:

$$
\begin{gathered}
2 \mathrm{CO} \rightarrow \mathrm{C}_{(\mathrm{g}-\mathrm{Fe})}+\mathrm{CO}_{2} \\
\mathrm{CH}_{4} \rightarrow \mathrm{C}_{(\mathrm{g}-\mathrm{Fe})}+2 \mathrm{H}_{2} \\
\mathrm{CO}+\mathrm{H}_{2} \leftrightarrow \mathrm{C}_{(\mathrm{g}-\mathrm{Fe})}+\mathrm{H}_{2} \mathrm{O}
\end{gathered}
$$

A variety of applications of steel carburizing were explored for decades with typical examples of automotive gears. This includes also stainless steels, in particular the ferritic and austenitic stainless grades. Recently, the carburizing process creates a growing attention in area of martensitic stainless steels. A comparison of hardness depth profiles for all three 
families of stainless steels is shown in Fig. 19. A relatively novel, low temperature gas carburizing at $470^{\circ} \mathrm{C}$ increases the surface hardness of AISI 316 austenitic stainless steel from $200 \mathrm{HV}$ to $1000 \mathrm{HV}$ through extreme supersaturation of up to 12 at.\% carbon in the solid solution [73] [74]. After treatment, two types of carbides $\mathrm{M}_{5} \mathrm{C}_{2}$ and $\mathrm{M}_{7} \mathrm{C}_{3}$ form with long needles or laths morphology, exhibiting the special orientation relationship with the austenitic matrix (Fig. 20). It is claimed that the carburizing technique which combines the superplastic deformation and the carbon diffusion generates a thicker layer and substantially higher hardness [75]. For duplex stainless steel JIS US329J1 the surface hardness of $1648 \mathrm{HV}$ is achieved as compared to $1300 \mathrm{HV}$ for conventional carburizing. The plasma carburizing of AISI 410 stainless steel in a gas mixture of $80 \% \mathrm{H}_{2}+20 \%$ Ar with 0.5 $1 \%$ of $\mathrm{CH}_{4}$ by volume, leads to surface hardness of $600-800 \mathrm{HV}$ with no evidence of reduced corrosion resistance [76].

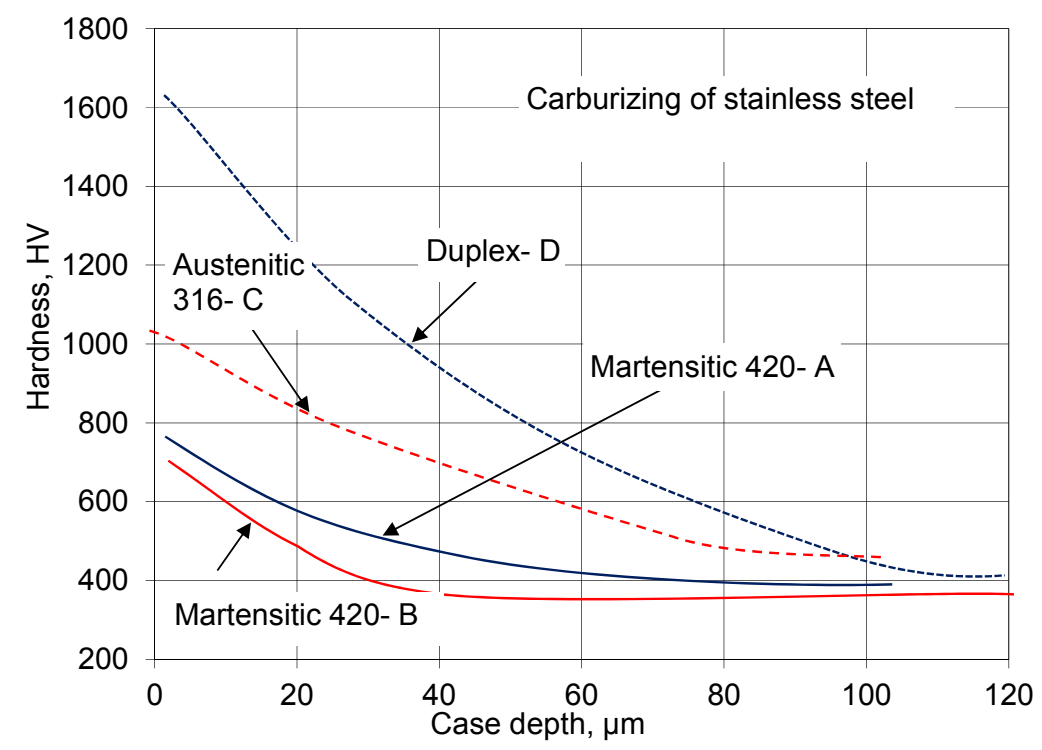

Figure 19. Hardness depth profiles for carburized stainless steel of different grades: A - AISI 420 martensitic stainless steel, carburized in low temperature plasma at $450{ }^{\circ} \mathrm{C}$ for $4 \mathrm{~h}$ in $1 \% \mathrm{CH}_{4}$ [76]; $\mathrm{B}-$ as A but $\mathrm{CH}_{4}$ concentration of $0.5 \%$; C - AISI 316 austenitic stainless steel, gas carburized at $470{ }^{\circ} \mathrm{C}$ for 246 h [74]; D -JIS SUS329J1 duplex stainless steel, superplastically deformed and carburized in powder at $950{ }^{\circ} \mathrm{C}$ for $8 \mathrm{~h}$ [75] (with permission from Elsevier Science)

In the area of non-ferrous alloys, carburizing is used to increase the wear resistance of some titanium alloys. As a result of double-glow plasma carburizing of the Ti2 $\mathrm{AlNb}$ orthorhombic alloy, the layer of $40 \mu \mathrm{m}$ with a hardness of $1051 \mathrm{HV}$ and decreasing carbon content develops [77]. Also plasma carburizing of pure titanium in hydrogen free atmosphere is capable of creating the superficial carburized layer with special characteristics [78]. Of novel applications, carburizing of silicon is portrayed as an inexpensive in situ method of forming graphene on silicon wafer [79]. The process is seen as an alternative to the silicon technology. 
During carburizing of silicon with carbon, pre-deposited from a carbon source a 3C-SiC(111) film forms because it is well lattice-matched with $\mathrm{Si}(110)$. The buffer layer of 3C-SiC(111) consists of hexagonal arrays that act as templates for graphene nucleation and growth.
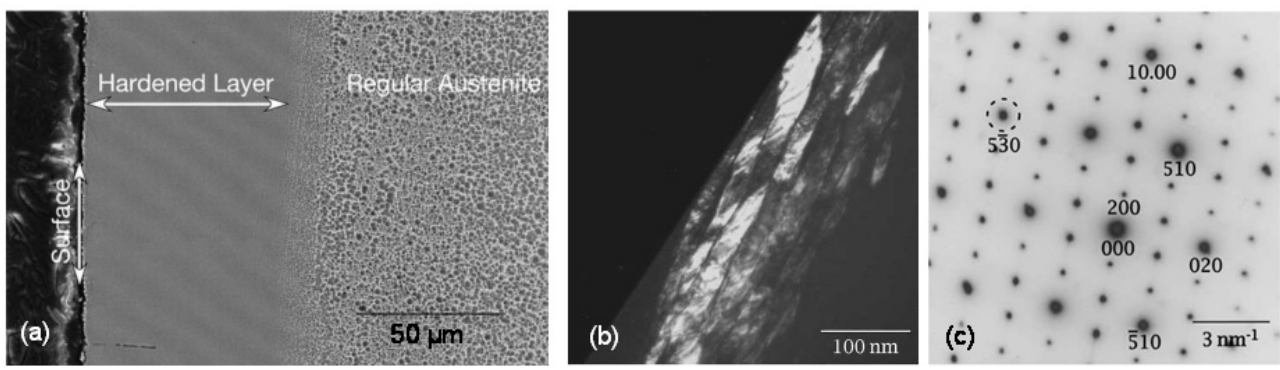

Figure 20. Optical microstructure of AISI 316 austenitic stainless steel after carburizing at $470{ }^{\circ} \mathrm{C}$ for 246 h (a) [74] and TEM image with selected area electron diffraction pattern showing carbide morphology (b, c) [73] (with permission from Elsevier Science)

\section{Carbonitriding}

Carbonitriding is a process similar to carburizing whereby a source of nitrogen is added to the carburizing atmosphere which results in simultaneous incorporation of carbon and nitrogen into alloy surface. Sometimes carbonitriding is confused with nitrocarburizing. It is usually a two-step treatment, conducted at temperatures of $800-940{ }^{\circ} \mathrm{C}$ in an environment containing both carbon and nitrogen and is followed by quenching. At carbonitriding temperatures, which are substantially higher than that used during nitriding or nitrocarburizing, steel is in the austenitic state, having high solubility of carbon. To improve toughness, quenching is followed by the second step of low-temperature tempering or stress relieving. At the processing stage, nitrogen inhibits diffusion of carbon, resulting in thinner case, improves hardenability and forms nitrides. After treatment, a presence of nitrogen in carburized steel increases hardness, wear resistance and delays tempering. The latter is of importance for elevated temperature applications. Carbonitriding is widely accepted for surface improvement of plain carbon steels, having low hardenability. According to the comparative study of both processes, carbonitriding and nitrocarburizing develop the compressive stress and are associated with the size and shape distortion [80]. However, nitrocarburizing causes lower compressive stress and size/shape distortion, as is the case for SAE 1010 steel.

Since carbon and nitrogen form with titanium the hard carbides and nitrides, carbonitriding is applicable to titanium and its alloys. In case of laser gas assisted carbonitriding of Ti-6Al$4 \mathrm{~V}$ alloy, the $55 \mu \mathrm{m}$ thick layer composed of $\mathrm{TiC}_{\mathrm{x}} \mathrm{N}_{1-\mathrm{x}}, \mathrm{TiN}$ and $\mathrm{TiC}$ phases grow [81]. In case of pure titanium, carbonitriding at $850{ }^{\circ} \mathrm{C}$ for $5 \mathrm{~h}$ forms the near-surface layer of carbonitrides and thick layer of $\alpha$-stabilized solid solution of titanium with nitrogen and oxygen [82]. As the partial nitrogen pressure changes from $105 \mathrm{~Pa}$ to $100 \mathrm{~Pa}$ and to $10 \mathrm{~Pa}$ the surface hardness decreases and composition alters to $\mathrm{TiC}_{0.25} \mathrm{~N}_{0.75}$ to $\mathrm{TiC}_{0.50} \mathrm{~N}_{0.50}$ and $\mathrm{TiC}_{0.52} \mathrm{~N}_{0.48}$, respectively. 


\section{Boronizing}

During boronizing, called also boriding, the surface layer of material is saturated with boron. The process is performed in solid, liquid or gaseous medium and is applicable to any ferrous material as well as to alloys of $\mathrm{Ni}, \mathrm{Co}$ or $\mathrm{Ti}$. In case of steel it is carried out at temperatures between 840 and $1050^{\circ} \mathrm{C}$ for up to $10 \mathrm{~h}$ creating borides $\mathrm{FeB}$ and $\mathrm{Fe}_{2} \mathrm{~B}$, which have a needle-like structure and hardness reaching $2000 \mathrm{HV}$. In addition to improving wear resistance, boronizing enhances also the corrosion resistance and oxidation resistance at temperatures of up to $850{ }^{\circ} \mathrm{C}$. The main disadvantage of boronizing is the brittleness of the compound layer, especially the FeB phase.

\subsection{Application range}

For high-carbon-bearing steel AISI 5100, boronizing in solid medium of $\mathrm{B}_{4} \mathrm{C}$, $\mathrm{SiC}$ and $\mathrm{KBF}_{4}$ at temperatures $800-950{ }^{\circ} \mathrm{C}$ for up to $8 \mathrm{~h}$ creates the single phase layer of $\mathrm{Fe}_{2} \mathrm{~B}$ with a saw tooth morphology and hardness reaching $1800 \mathrm{HV}$ [83]. The growth rate of boride layer is controlled by boron diffusion in the $\mathrm{Fe}_{2} \mathrm{~B}$ layer with the boronizing activation energy of 106 $\mathrm{kJ} / \mathrm{mol}$. For M2 high speed cutting steel, boronizing at $850-950{ }^{\circ} \mathrm{C}$ for up to $8 \mathrm{~h}$, produces the smooth and compact layer with a thickness of up to $130 \mu \mathrm{m}$ and hardness of 1600-1900 HV [84]. For tool steels the high hardness associated with a presence of borides causes a substantial reduction in toughness [85]. When applied to AISI 304L stainless steel by laser technology, boronizing develops the $\mathrm{FeB}, \mathrm{Fe}_{2} \mathrm{~B}, \mathrm{Cr}_{2} \mathrm{~B}, \mathrm{Cr}_{23} \mathrm{C}_{6}, \mathrm{Fe}_{3} \mathrm{C}$ and $\mathrm{B}_{4} \mathrm{C}$ phases with surface hardness reaching 1490-1900 HV [86].

Boronizing is applicable to titanium alloys and a pack process at $950^{\circ} \mathrm{C}$ creates a compact, uniform layer composed of $\mathrm{TiB}_{2}$ and $\mathrm{TiB}$ compounds [87]. Also, boronizing of pure nickel in powder-pack at $850-950{ }^{\circ} \mathrm{C}$ for up to $8 \mathrm{~h}$ creates the $237 \mu \mathrm{m}$ thick surface layer composed of $\mathrm{Ni}_{2} \mathrm{~B}, \mathrm{Ni}_{5} \mathrm{Si}_{2}$ and $\mathrm{N}_{2} \mathrm{Si}$ phases with a hardness exceeding $980 \mathrm{HV}$ [88]. The laser boronizing of nodular iron increases hardness five times and produces the fine-crystalline, homogeneous structure of iron borides [89]. The commercial boronizing Titancote ${ }^{\mathrm{TM} B}$ generates a diffusion layer of complex borides with a thickness of 10-200 $\mu \mathrm{m}$ and hardness of 1600-1800 HV with applications in tooling, oil, gas or general components [90]. In addition to titanium, also other refractory metals such as tantalum, niobium, tungsten and also cobalt-chromium alloys benefit from boronizing. One of many advantages is increasing the surface strength without negatively affecting a biocompatibility.

\subsection{Treatments with a boronizing step}

The two stage treatment called borochromizing consists of chromium plating followed by diffusion boronizing and heat treatment. After powder boronizing of the $20 \mu \mathrm{m}$ thick chromium coating on $\mathrm{C} 45$ carbon steel at $950{ }^{\circ} \mathrm{C}$ for $4 \mathrm{~h}$, the microstructure, thickness and microhardness are similar to the boride layer [91]. An additional treatment with laser, creates a solid solution or boride eutectics with martensite, reducing maximum hardness to $850 \mathrm{HV}$. An example of the boride layer grown on pure chromium after boriding in a solid medium at $940{ }^{\circ} \mathrm{C}$ for $8 \mathrm{~h}$, is shown in Fig. 21a [92]. The process of borochromizing can also 
be conducted, exploring exclusively thermodiffusion and the duplex salt bath immersion. During such a treatment, chromizing at $1050{ }^{\circ} \mathrm{C}$ is followed by boronizing at $950-1050{ }^{\circ} \mathrm{C}$ [93]. For DIN 1.2714 steel the treatment leads to a variety of phases such as $\mathrm{CrB}, \mathrm{Cr} 2 \mathrm{~B}, \mathrm{FeB}$ and $\mathrm{Fe}_{2} \mathrm{~B}$ with the boron diffusion in the pre-chromized layer being the rate controlling step. The single-stage boroaluminizing is practiced in the gas phase at temperatures of $850-900{ }^{\circ} \mathrm{C}$ with controlled ratios of $\mathrm{BF}_{3}$ and $\mathrm{AlF}_{3}$ [94].

Borocarburizing is another two-step process where carburizing is followed by boronizing to generate boronitrides. It was proven that carburizing preceding boronizig reduces brittleness of boronized layers since the hardness gradient between iron borides and the carburized substrate becomes shallower. For $17 \mathrm{CrNi6}-6$ steel, heat treated with laser after borocarburizing, three zones are distinguished, iron borides $\mathrm{FeB}+\mathrm{Fe} 2 \mathrm{~B}$ of the modified morphology the hardened carburized zone (heat affected zone) and the carburized layer without heat effect [95]. The laser heat-treated borocarburized layer is characterized by higher hardness than the carburized layer, which is attributed to the presence of $\mathrm{FeB}$ and $\mathrm{Fe}_{2} \mathrm{~B}$ phases. For low carbon steels containing $\mathrm{Cr}$ and $\mathrm{Ni}$, the borocarburized layer of $\mathrm{FeB}$ and $\mathrm{Fe}_{2} \mathrm{~B}$ with a microstructure shown in Fig. 21b, reached a hardness of 1500-1800 HV with a sub-layer zone being in the range of 700-950 HV [96]. An advantage of the borocarburized layer is in the higher frictional resistance as compared with the single treatment of either boronizing or carburizing. As an extension of borocarburizing, carbonitrided surfaces may be subjected to boronizing hence creating complex $(B+C+N)$ diffusion layers [97]. Although borocarbonitriding shows a tendency to reduce the depth of iron borides zone and the microhardness gradient across the surface the resultant wear resistance is higher than that after individual processes. Another benefit of borocarbonitriding is borocarbonitriding is the lower lower temperature and shorter time in comparison with borocarburizing.
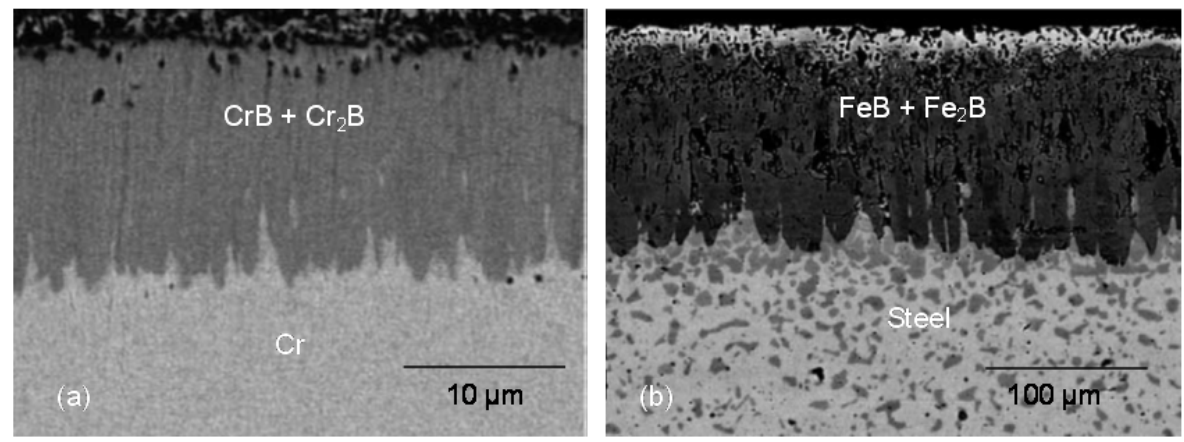

Figure 21. Cross-sectional microstructure after boronizing: (a) pure chromium, solid medium, $940{ }^{\circ} \mathrm{C}, 8$ h [92]; steel $0.15 \% \mathrm{C}, 1.69 \% \mathrm{Cr}$ and $1.53 \% \mathrm{Ni}, 930{ }^{\circ} \mathrm{C}, 20 \mathrm{~h}$ [96] (with permission from Elsevier Science)

\section{Chromizing}

The purpose of diffusion chromizing is to enrich surface layers of an alloy with chromium. As other diffusion processes it may be carried out by powder pack, salt bath or fluidized bed. The compound surface layer is formed by a reaction between the carbide former, such 
as $\mathrm{Cr}$ deposited on the surface and carbon in the substrate. The outcome shows similar properties to coatings produced by CVD and PVD. In some sources, the process is divided into soft chromizing, when carbon content in a substrate is below $0.1 \%$ and hard chromizing for the carbon content in a substrate exceeding $0.3 \%$. As negative features of chromizing, the shallow penetration depth and the distinct interface with the substrate are often quoted. Both features are caused by the diffusion kinetics of chromium in steel.

\subsection{Process and applications}

The typical chemistry of chromizing powder consists of $30 \%$ of ferrochromium $(71 \% \mathrm{Cr}$, $0.03 \% \mathrm{C}$ and $\mathrm{Fe}$ as a balance), $2.5 \%$ ammonium chloride activator and $67.5 \%$ of alumina powder filler [98]. The diffusion depth depends on the temperature and substrate chemistry. It obeys the parabolic rate law and increases with chromizing time and carbon content in the matrix. For temperature of $950{ }^{\circ} \mathrm{C}$ and reaction time of $9 \mathrm{~h}$, the diffusion layer thickness reaches 13.2, 22.5 and 27.0 for AISI 1020, 1045 and 1095 steels, respectively. The growth mechanism of chromium diffusion coatings on ferrous alloys was intensively studied in 1980s [99] along with the role of pack geometry, substrate composition, type of halide activator, inner filler, time temperature and chromium source.

Chromizing kinetics can be improved by a combination of conventional thermochemical process with recently developed surface mechanical attrition treatment. The latter aims at refining grains of surface layers into a nanometer range by the repeated plastic deformation such as high velocity ball impacting or mechanical grinding [100]. When a $20 \mu \mathrm{m}$ thick surface layer with grain size of $10 \mathrm{~nm}$ was formed on AISI H13 tool steel, it provided a substantial enhancement of chromium diffusion. The two-step thermochemical treatment of chromizing, with the first step conducted within the stability limit of nano-structures at 600 ${ }^{\circ} \mathrm{C}$ for $2 \mathrm{~h}$, followed by the second-step treatment at $1050{ }^{\circ} \mathrm{C}$ for $4 \mathrm{~h}$, created the $30 \mu \mathrm{m}$ thick layer with a gradient of chromium concentration. The layer contained $(\mathrm{Cr}, \mathrm{Fe}){ }_{23} \mathrm{C}_{6}$ and $(\mathrm{Cr}, \mathrm{Fe})_{2} \mathrm{~N}_{1-x}$ particles with a size below $200 \mathrm{~nm}$.

\subsection{Treatments with a chromizing step}

Chromizing is often combined into a two-step treatment with nitriding, nitrocarburizing or boronizing. For AISI 1010 steel, nitrocarburized at $572{ }^{\circ} \mathrm{C}$ for $2 \mathrm{~h}$, and subsequently chromized by the pack method in a powder of ferrochromium, ammonium chloride and alumina at $1000^{\circ} \mathrm{C}$ for up to $4 \mathrm{~h}$, the layer thickness reaches up to $13 \mu \mathrm{m}$ with a hardness of $1800 \mathrm{HV}$ [101]. The layer consists of $\mathrm{Cr}_{2} \mathrm{~N}$ and $(\mathrm{Cr}, \mathrm{Fe})_{2} \mathrm{~N}_{(1-x)}$ phases. In another example, AISI 1045 steel was first nitrided with $2 \mu \mathrm{m}$ thick compound layer and hardness of $740 \mathrm{HV}$ and then chromized in powder mixtures consisting of ferrochromium, ammonium chloride and alumina at $1000^{\circ} \mathrm{C}$ for $2 \mathrm{~h}$ [102]. Chromizing of nitrided layer resulted in formation of $\mathrm{Cr}_{2} \mathrm{~N}$ chromium nitride and $\mathrm{Fe}_{3} \mathrm{~N}$ iron nitrides. Although an increase in hardness was observed, it did not lead to an improvement in wear resistance. When combining chromizing with boronizing, pack chromium treatment of previously boronized bearing steel provides high wear resistance, particularly in sliding applications [103]. 


\section{Thermo-reactive diffusion}

The thermal diffusion (TD), thermo-reactive deposition/diffusion (TRD) or TD-Toyota diffusion process is a high temperature treatment which generates a surface layer of carbides on steel as well as other carbon-containing materials such as nickel or cobalt alloys. In the treatment, carbon in the steel substrate diffuses into the deposited layer with a carbide-forming element such as vanadium, niobium, tantalum, chromium, molybdenum or tungsten. Then, the diffused carbon reacts, forming a compact, metallurgically-bonded coating with a thickness of up to $20 \mu \mathrm{m}$. The process is carried out at temperatures from 800 to $1250{ }^{\circ} \mathrm{C}$ for up to several hours. Due to the high temperature, steel requires bulk hardening either directly from the TD temperature or after the separate re-heating cycle. The typical hardness of vanadium carbide coatings, obtained using the salt bath TD process, reaches 3200-3800 V [104]. Also, niobium carbide $\mathrm{NbC}$ coatings exhibit the high hardness, wear resistance and low friction coefficient along with the high melting point. Coatings are produced by the steel immersion in the molten bath consisting of borax $\left(\mathrm{Na}_{2} \mathrm{~B}_{4} \mathrm{O}_{7}\right)$, boric acid $\left(\mathrm{B}_{2} \mathrm{O}_{3}\right)$ and ferroniobium at $900-1100{ }^{\circ} \mathrm{C}$ for up to $10 \mathrm{~h}$ [105]. The diffusion of elements from niobium carbide coating to the steel and from the substrate to the coating was found to control the process kinetics for a bath containing more than $10 \%$ of ferro-niobium.

\section{Hybrid thermochemical treatments}

There are a number of surface modification technologies where thermochemical process is a single step in the multi-step treatment. An example of such hybrid is a concept of creating functionally graded materials, exploring a combination of coating and thermochemical treatment (Fig. 22). The single step process of deposition of thick coating with the high hardness is often difficult since they develop microcracks due to a generation of high internal stress [106]. Functionally graded materials offer new strategies for the implementation of high-performance structures in engineering components. They are comprised of continuous or discontinuous varying composition and/or microstructure over definable geometric orientations or distances. As a result they exhibit some unique properties which are beneficial for specific engineering applications. For example, the use of functionally graded systems in high-temperature components can enhance the adhesion and thermo-mechanical response of ceramic coatings deposited on metallic substrates [107].

The difference in phase transformation temperatures between the steel substrate and the Fe$10 \% \mathrm{Ni}$ electrolytic deposit is an important factor of the thermal treatment proposed [108] [109]. At temperatures below $727^{\circ} \mathrm{C}$, the steel containing $0.9 \% \mathrm{C}$ is composed essentially of pearlite, i.e. $\alpha+\mathrm{Fe}_{3} \mathrm{C}$. At the same time, the temperature of the $\alpha-\gamma$ transformation of the coating is approximately $680{ }^{\circ} \mathrm{C}$. By selecting the temperature between 680 and $727{ }^{\circ} \mathrm{C}$, the thermal diffusion treatment can be conducted at the coexistence of $\alpha$ (substrate) - $\gamma$ (coating) diffusion couple. By contrast, during annealing at a temperature above $727^{\circ} \mathrm{C}$, both the steel substrate and the coating are composed exclusively of austenite $(\gamma)$. The co-existence of the $\alpha$ - $\gamma$ or the $\gamma-\gamma$ diffusion couples leads to the essentially different redistribution of carbon across the coating thickness and the surface region of the steel substrate. 


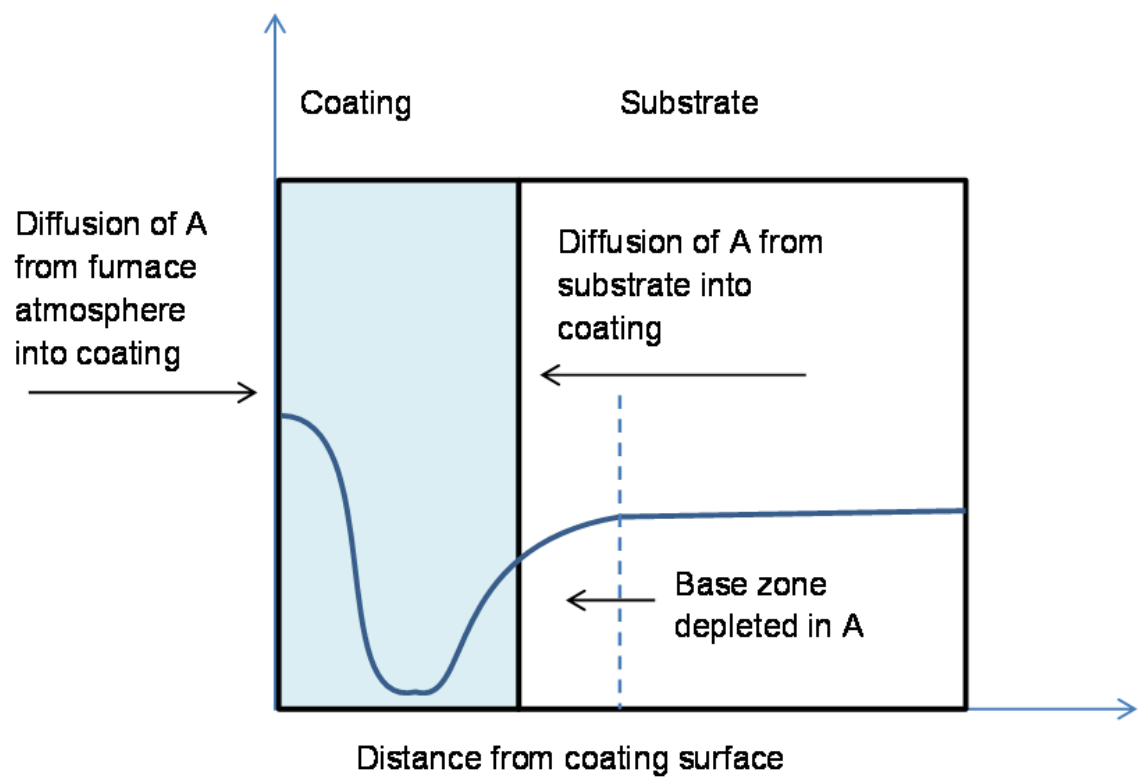

Figure 22. Concept of thermochemical treatment of a coating, exploring simultaneous diffusion from an environment and from the substrate

\subsection{Carburizing and diffusion annealing at a coexistence of the $\alpha-\gamma$ diffusion couple}

During annealing at temperatures below $\alpha-\gamma$ transformation of the steel substrate, the coating already contains a significant amount of the $\gamma$ phase, which is the solid solution of $\mathrm{Ni}$ in $\gamma \mathrm{Fe}$ (fcc). At the same time, the substrate during annealing remained fully pearlitic. Thus, at the annealing temperature, cementite coagulated, dissolved and acted as a source of carbon, diffusing towards coating. Due to a relatively low temperature, the transport of large amounts of carbon for long distances within coating was difficult. After $30 \mathrm{~min}$ of annealing at $710{ }^{\circ} \mathrm{C}$, the mean square root displacement of the carbon in austenite is as low as $32 \mu \mathrm{m}$. However, the carbon concentration gradient within the coating caused substantial modifications of the microstructure formed after cooling from annealing temperatures.

An example of cross-sectional image of the microstructure formed after cooling from the two-phase $(\alpha-\gamma)$ range of coating, is shown in Fig. 23a. The coating cooled from the onephase region $\gamma$ comprises continuously graded microstructures caused primarily by differences in carbon content at the coating-gas and coating substrate interface. Since the substrate was not transformed, the decarburization is seen as a thin ferritic layer, adjacent to fully pearlitic microstructure. The hardness depth profile for the treatment performed at 710 ${ }^{\circ} \mathrm{C}$, is represented by the lower curve in Fig. 24. An increase in hardness is seen in the region adjacent to the substrate and to the outer surface, due to diffusion of carbon from these two directions. 


\subsection{Carburizing and diffusion annealing at a coexistence of the $\gamma$ - $\gamma$ diffusion couple}

Significantly different changes in coating microstructure are observed after annealing at temperatures higher than the $\alpha-\gamma$ transformation of the steel substrate [109]. For example, at $1000{ }^{\circ} \mathrm{C}$ the diffusion coefficient of carbon in austenite $\mathrm{Dc}^{\gamma}$ is equal to $2.5 \times 10^{-11} \mathrm{~m}^{2} \mathrm{~s}^{-1}$ which corresponds to the mean root square displacement of almost $270 \mu \mathrm{m}$ after $30 \mathrm{~min}$. This means that carbon is capable penetrating the entire coating thickness.

At temperatures above $727{ }^{\circ} \mathrm{C}$, diffusion of carbon within the substrate, towards the substrate-coating interface, takes place in the austenite. As a result, the distribution of carbon in the substrate after cooling has a significantly different character than that described for $\alpha-\gamma$ diffusion couple. In general, the substrate does not show a ferritic layer but a continuously graded microstructure composed of ferrite and pearlite with an increasing contribution of pearlite, while moving inward from the substrate-coating interface. After $30 \mathrm{~min}$ annealing at $1000{ }^{\circ} \mathrm{C}$, the ferritic and pearlitic region is approximately $400 \mu \mathrm{m}$ thick.

Carburizing at $920^{\circ} \mathrm{C}$ allows a higher enrichment of the coating in carbon and the higher hardness after cooling as showed by two upper curves in Fig. 24. The lower hardness in the regions close to the substrate and the outer surface can be explained on the basis of microstructural observations (Fig. 23b). While the coating carburized at $710{ }^{\circ} \mathrm{C}$ has a microstructure of acicular ferrite and bainite, the coating carburized at $920{ }^{\circ} \mathrm{C}$ is composed of martensite and retained austenite [109]. The high volume fraction of retained austenite in the regions close to the substrate and the outer surface caused the lower hardness.
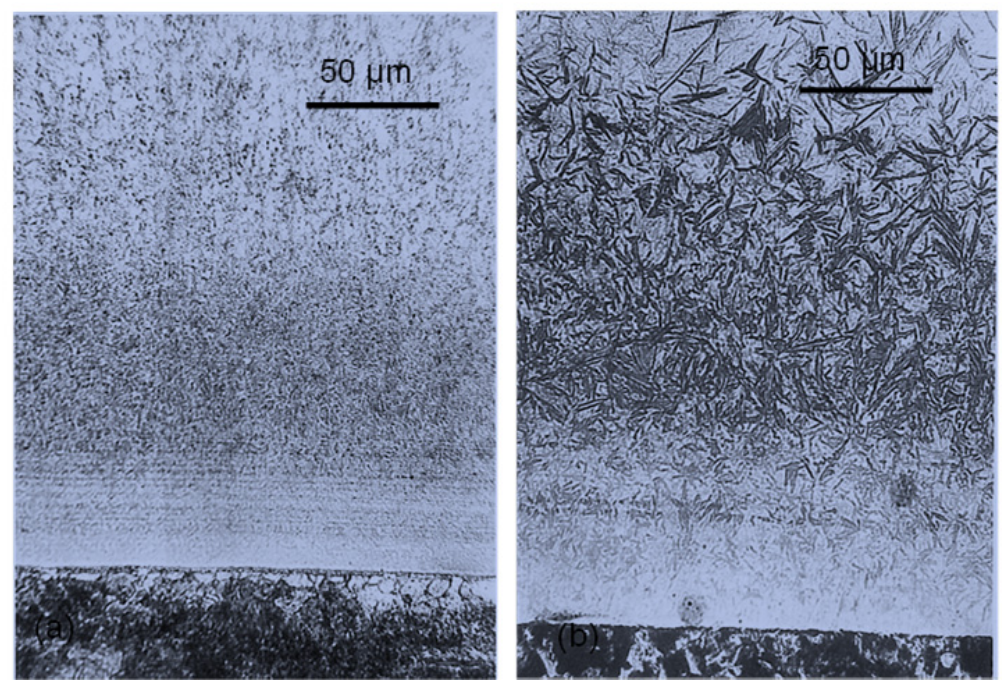

Figure 23. Microstructure of $\mathrm{Fe}-10 \% \mathrm{Ni}$ coating on steel substrate after carburizing at temperatures of $670^{\circ} \mathrm{C}(\mathrm{a})$ and $920^{\circ} \mathrm{C}(\mathrm{b})$ [109] (with permission from Springer Verlag) 


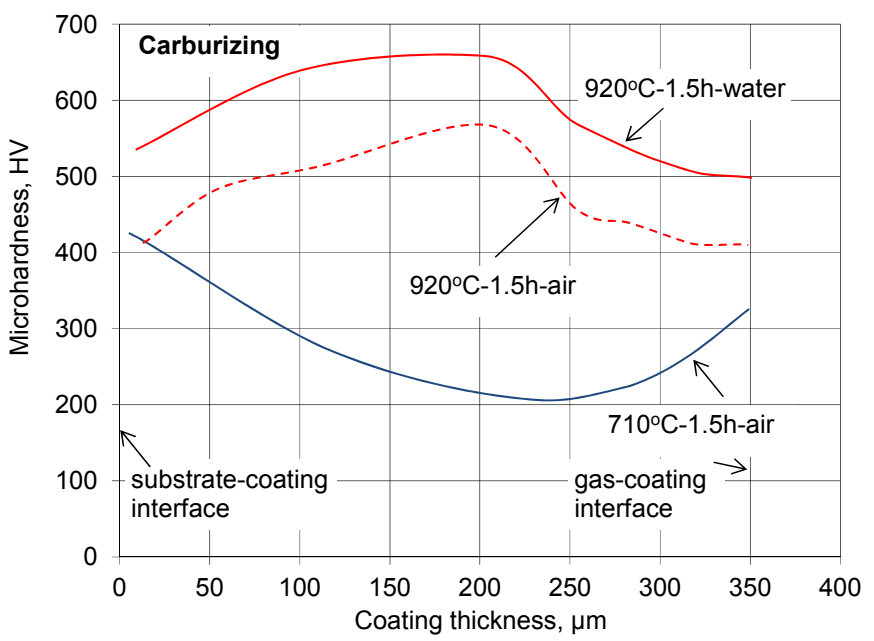

Figure 24. Hardness depth profile within Fe-10\%Ni coating on steel substrate after carburizing [109] (with permission from Springer Verlag)

\subsection{Carbonitriding and diffusion annealing at a coexistence of the $\alpha-\gamma$ diffusion couple}

This hybrid treatment explores simultaneous carbonitriding at the coating gas interface and carburizing at the coating-substrate interface. At carbonitriding temperatures the substrate also acts as a source of carbon and, in fact, during these processes the flux of the element causing hardening $(\mathrm{C}, \mathrm{N})$ is moving from two interfaces the substrate/coating and gas/coating [109]. The resultant microstructure is shown in Fig. 25.
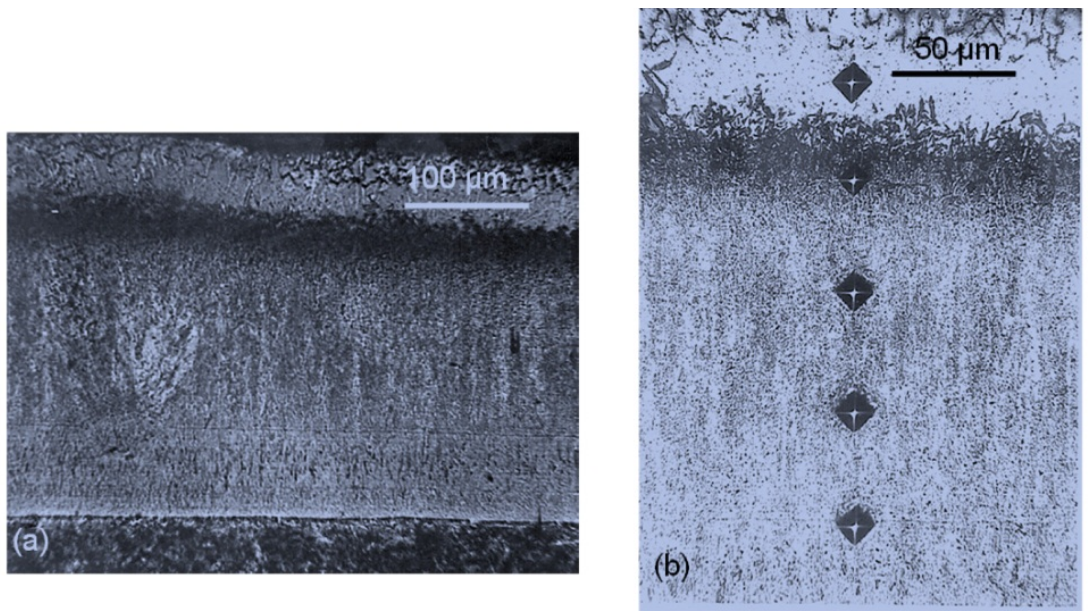

Figure 25. Microstructure of Fe-10\%Ni coating after nitrocarburizing at $670{ }^{\circ} \mathrm{C}$ for $1.5 \mathrm{~h}$ in solid medium [109] (with permission from Springer Verlag) 
The microhardness profile across the coating exhibits the maximum located in the subsurface region (Fig. 26). A comparison with the corresponding microstructure indicates that the hardness peak is caused by a layer of carbonitrides, typically situated in the near-surface region. It should be emphasized that during carbonitriding, the microstructural changes in the coating are accompanied by the changes in the substrate. The extent of those changes is essentially the same as that described previously for diffusion annealing.

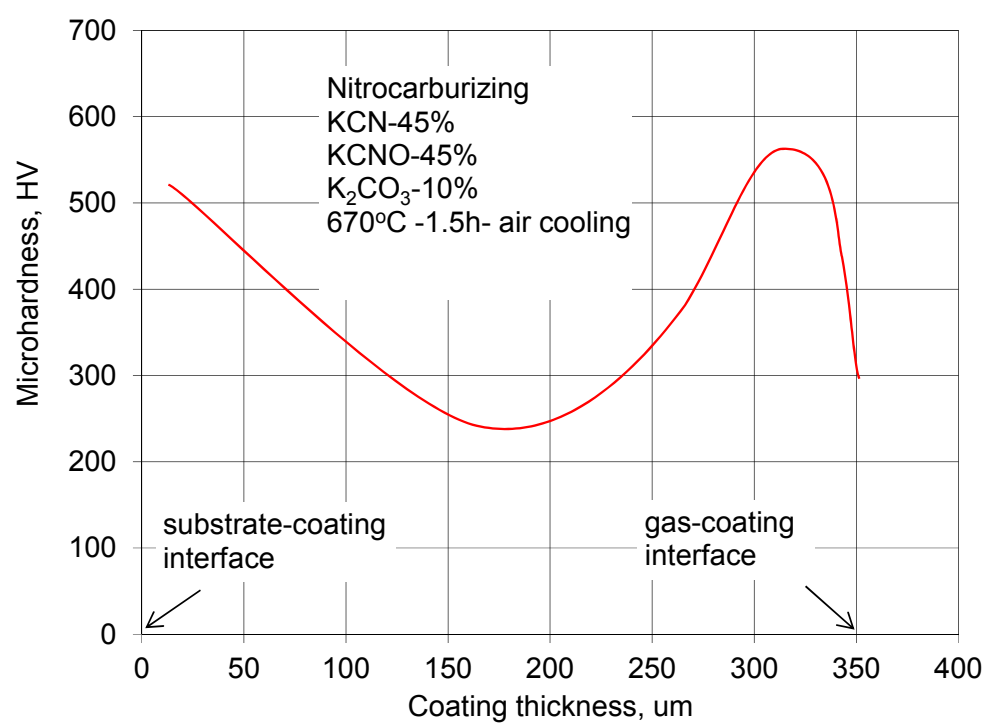

Figure 26. Hardness depth profile within Fe-10\%Ni coating on steel substrate after nitrocarburizing [109] (with permission from Springer Verlag)

\section{Summary}

This chapter shows a variety of surface modification technologies, exploring the phenomenon of thermochemical diffusion. Although an idea of the thermochemical treatment originated at the beginning of the $20^{\text {th }}$ century, it is still a subject of scientific research. At the commercial level, there is a continuous improvement of existing technologies, expansion to novel treatments and a search for unique applications. Of particular interests are hybrids which explore a combination of conventional thermochemical processes with new techniques of surface engineering, including surface deformations, cladding, coatings or laser modifications. In practice, a selection of the optimum technique depends on the component size, geometry, material chemistry, service requirements and the process economy. In recent years, also an environmental aspect is getting a growing attention. The key to benefit from opportunities created by thermochemical treatments is knowledge of capabilities of each technology for a particular substrate material under specific service conditions and its implementation at the stage of a component design. 


\section{Author details}

Frank Czerwinski*

CanmetMATERIALS, Natural Resources Canada, Hamilton, Ontario, Canada

\section{References}

[1] D. Pye, Practical Nitriding and Ferritic Nitrocarburizing, Materials Park, Ohio: ASM International, 2003.

[2] J. Georges, "US Patent, Nitriding process and nitriding furnace therefore, Plasma Metal SA". Patent 5,989,363, 1999.

[3] J. Yeh, S. Chen, J. Lin, J. Gan, T. Chin, T. Shun, C. Tsau and S. Chang, "Nanostructured high-entropy alloys with multi principal elements:Novel alloy design and outcomes," Advanced Engineering Materials, vol. 6, pp. 299-303, 2004.

[4] M. Yoshida, M. Okumiya, R. Ichiki, C. Tekmen, W. Khalifa, T. Y. and T. Hara, "A novel method for the production of AlN film with high adhesion on Al substrate," Journal of Plasma Fusion Research, vol. 8, pp. 1447-1450, 2009.

[5] M. Brady, K. Weisbrod, C. Zawodzinski, I. Paulauskas and R. Buchanan, "Assessment of thermal nitriding to protect metal bipolar plates in polymer electrolyte membrane fuel cells," Electrochemical and Solid State Letters, vol. 5, no. 11, pp. A245-247, 2001.

[6] S. Singaravelu, J. Klopf, G. Krafft and M. Kelley, "Laser nitriding of niobium for application to superconducting radio-frequency accelerator cavities," Journal of Vacuum Science and Technology B, vol. 29, no. 6, p. 6, 2011.

[7] A. Turk, O. Ok and C. Bindal, "Structural characterization of fluidized bed nitrided steels," Vacuum, vol. 80, no. 4, pp. 332-342, 2005.

[8] M. Korvin, W. K. Liliental, C. D. Morawski and G. J. Tymowski, "Design of Nitrided and Nitrocarburized Materials," in Handbook of Metallurgical Process Design Edited by G.E. Totten, K. Funatani and L. Xie, New York, Marcel Dekker Inc., 2005, pp. 545-590.

[9] J. Dossett and H. Boyer, Practical Heat Treating, Materials Park, Ohio: ASM International, 2006.

[10] Aerospace Materials Specification 2759-8A, Ion Nitriding, 2007.

[11] Advanced Heat Treat Corp, 2012. [Online]. Available: www.ahtweb.com.

[12] A. Ricard, J. Deschamps, J. Godard, L. Falk, H. Michel and A. Eng, "Nitrogen atoms in ArN2 flowing microwave discharge for steel surface nitriding," Materials Science and Engineering A, vol. 139, pp. 9-14, 1991.

[13] C. Li, T. Bell and H. Dong, "A study of active screen plasma nitriding," Surface Engineering, vol. 18, no. 3, pp. 174-181, 2002.

[14] P. Schauf, "Iron nitrides and laser nitriding of steel," Hyperfine Interactions, vol. 111, pp. 113-119, 1998.

\footnotetext{
* Corresponding Author
} 
[15] D. Manova, D. Hirsch, J. Gerlach, T. Hoche, S. Mandl and H. Neumann, "Nitriding of Fe-Cr-Ni steel by low energy ion implantation," Surface and Coating Technology, vol. 11, pp. 2443-2447, 2008.

[16] R. Wei, J. Vajo, J. Matossian, P. Wilbur, J. Davis, D. Williamson and G. Collins, "A comparative study of beam ion implantation, plasma ion implantation and nitriding of AISI 304 stainless steel," Surface and Coatings Technology, vol. 83, no. 1-3, pp. 235-242, 1996.

[17] H. Wriedt, N. Gokcen and R. Nafziger, Bulletin of Alloy Phase Diagrams, vol. 8, p. 355, 1997.

[18] N. Kardonina, A. Yurovskikh and A. Kolpakov, "Transformations in the Fe-N system," Metal Science and Heat Treatment, vol. 52, no. 9, pp. 457-467, 2010.

[19] T. Woehrle, A. Leineweber and E. Mittemeijer, "The shape of Nitrogen concentrationdepth profiles in gamma prime layers growing on alfa iron substrates; The thermodynamics," Metallurgical and Materials Transactions, vol. 43A, pp. 610-618, 2012.

[20] B. Kooi, M. Sommers and E. Mittemeijer, "An evaluation of the Fe-N phase diagram considering long range order of $\mathrm{N}$ atoms in gamma prime Fe4N and epsilon Fe2N," Metallurgical and Materials Transactions A, vol. 27A, pp. 1996-1061, 1996.

[21] T. Gressman, M. Wohlschlogel, S. Shan, U. Welzel, A. Leineweber, E. Mittemeijer and Z. Liu, "Elastic anisotropy of gamma prime Fe4N and elastic grain interaction in gamma prime Fe4n(1-n) layers on alfa iron: first-principles calculations and diffraction stress measurements," Acta Materialia, vol. 55, pp. 5833-5843, 2007.

[22] S. Meka, K. Jung, E. Bischoff and E. Mittemeijer, "Unusual precipitation of amorphous silicon nitride upon nitriding Fe-2at\%Si alloy," Philosophical Magazine, vol. 92, no. 11, pp. 1435-1455, 2012.

[23] Aerospace Materials Specification 2759-10A, Automated Gaseous Nitriding Controlled by Nitriding Potential, 2006.

[24] J. Davis, Gear Materials, Properties and Manufacture, Materials Park, Ohio: ASM International, 2005.

[25] S. E. D. Engineering Directorate, "Process specification for ion nitriding, NASA," PRC 2004 REV A, 2006.

[26] V. Homberg and C. Floe, Nitralloy and nitriding including the new Floe process, Nitralloy Corporation, 1954.

[27] Z. Kolozsvary, "Influence of oxygen in plasma nitriding," International Heat Treatment and Surface Engineering, vol. 3, no. 4, pp. 153-158, 2009.

[28] P. Extended, "www.rubig.com," Rubig Engineering, 2012. [Online].

[29] E. Rolinski, A. Konieczny and G. Sharp, "Influence of nitriding mechanisms on surface roughness of plasma and gas nitrided/nitrocarburized gray cast iron," Heat Treating Progress, vol. 3, pp. 39-46, 2007.

[30] E. Rolinski, A. Konieczny and G. Sharp, "Nature of surface changes in stamping tools of gray and ductile cast iron during gas and plasma nitrocarburizing," Journal of Materials Engineering and Performance, vol. 1059, pp. 1-8, 2009. 
[31] V. Terentiev, M. Michugina, A. Kolmakov, V. Kvedaras and V. Ciuplys, "The effect of nitriding on fatigue strength of structural alloys," Mechanika, vol. 2, no. 64, pp. 12-22, 2007.

[32] T. Ericsson, "Residual stress caused by thermal and thermochemical surface treatments," Advances in Surface Treatments, vol. 87128, pp. 87-113.

[33] T. E. R. Watkins, C. Klepser and N. Jayarman, "Measurement and analysis of residual stress in epsilon iron nitride layers as a function of depth," Advances in X-ray analysis, vol. 43, pp. 31-38, 2000.

[34] "Nickel Alloy Nitriding Steels, Nickel Alloy Steels Data Book, Section 4, Bulletin A," The International Nickel Company, 1968.

[35] D. Girodin, "Deep nitrided 32CrMoV13 steel for aerospace bearings applications," NTN Technical Review, vol. 76, pp. 24-31, 2008.

[36] Ovako Ltd, 2012. [Online]. Available: www.ovako.com.

[37] S. Sun, X. Li and T. Bell, "X-ray diffraction characterization of low temperature plasma nitrided austenitic stainless steel," Journal of Materials Science, vol. 34, pp. 4793-4802, 1999.

[38] S. Corujeira Gallo and H. Dong, "New insight into the mechanism of low-temperaure active-screen plasma nitriding of austenitic stainless steel," Acta Materialia, vol. 67, pp. 89-91, 2012.

[39] K. Shetty, S. Kumar and P. Rao, "Ion nitriding of maraging steel (250 grade) for aeronautical applications," Journal of Physics: Conference Series, vol. 100, pp. 1-6, 2008.

[40] W. Tang, M. Chuang, S. Lin and J. Yeh, "Microstructure and mechanical properties of plasma nitrided A10.3CrFe1.5MnNi0.5 high entropy alloy," Metallurgical and Materials Transactions A, vol. 43A, pp. 2390-2400, 2012.

[41] "Edelstahl Witten-Krefeld GMBH," Nitrodur nitriding steels, [Online]. Available: www.schmolz-bickenbach.co.za.

[42] A. Zhecheva, W. Sha, S. Malinov and A. Long, "Enhancing the microstructure and properties of titanium alloys through nitriding and other surface engineering methods," Surface \& Coating Technology, vol. 200, pp. 2192-2207, 2005.

[43] A. Lisiecki and A. Klimpel, "Diode laser gas nitriding of Ti6Al4V alloy," Archives of Materials Science and Engineering, vol. 31, no. 1, pp. 53-56, 2008.

[44] M. Nagae, S. Okada, M. Nakanishi, J. Takada, Y. Hiraoka, Y. Takemoto, M. Hida, H. Kuwahara and M. Ki Yoo, "Nitriding of dilute Mo-Ti alloys at a low temperature of $1373 \mathrm{~K}$," International Journal of Refractory Metals and Hard Materials, vol. 16, no. 2, pp. 127-132, 1998.

[45] Editorial, "A new hard material for corrosive environments," Sealing Technology, vol. 1998, no. 50, pp. 10-12, 1998.

[46] F. Czerwinski, Magnesium Injection Molding, New York: Springer Verlag, 2008.

[47] A. Momozawa, S. Taubert, S. Nomura, K. Komurasaki and Y. Arakawa, "Nitriding of zirconium cathode for arc-heater testing in air," Vacuum, vol. 85, no. 5, pp. 591-595, 2010.

[48] R. Milani, R. Cardoso, T. Belmonte, C. Figueroa, C. Perottoni, J. Zorzi, G. Soares and I. Baumvol, "Nitriding of yttria-stabilized zirconia in atmospheric pressure microwave plasma," Journal of Materials Research, vol. 24, no. 6, pp. 2021-2028, 2009. 
[49] P. Visuttipitukul, T. Aizawa and H. Kuwahara, "Advanced plasma nitriding for aluminum and aluminum alloys," Materials Transactions, vol. 44, no. 12, pp. 2695-2700, 2003.

[50] M. Lee, S. Endoch and H. Iwata, "A basic study on the solid-state nitriding of aluminum by mechanical alloying using a planetary ball milling," Advanced Powder Technologies, vol. 8, pp. 291-297, 1997.

[51] L. Liu, A. Yamamoto, T. Hishida, H. Shoyama, T. Hara and H. Tsubakino, "Microstructure of nitrided AA5052 aluminum alloy formed by electron beam excited plasma technique," Materials Transactions, vol. 46, no. 3, pp. 687-690, 2005.

[52] J. Pongsopa, P. Visuttpitukul and B. Paosawatyanyong, "Surface hardening of aluminum-copper 2011 byRF plasma nitriding process," in 8th International Conference on Fracture and Strength of Solids 2010, Kuala-Lumpur, Thailand, 2011.

[53] P. Visuttipitukul and T. Aizawa, "Plasma nitriding design for aluminum and aluminum alloys," Surface Engineering, vol. 22, no. 3, pp. 187-195, 2006.

[54] M. Moradshahi, M. Mahamoudi, M. Amiri and A. Dabizadeh, "The effect of time and temperature on increasing the corrosion resistance of pure aluminum by DC plasma nitriding," Metallurgical Analysis, vol. 31, no. 1, pp. 7-13, 2011.

[55] I. Ghauri, R. Ahmad, F. Mubaric, N. Afzal, S. Ahmed and R. Ayub, "Effects of plasma nitriding on the tensile properties of Al-Mg-Si," Journal of Materials Engineering and Performance, pp. 1-4, 2011.

[56] J. Bosslet and M. Kreutz, "www.durferrite.de," [Online].

[57] T. Bell, Y. Sun and A. Suhadi, "Environmental and technical aspects of plasma nitrocarburizing," Vacuum, vol. 59, pp. 14-23, 2000.

[58] W. Liliental, L. Maldzinski, T. Tarfa and G. Tymowski, "Nitrocarburizing vs nitriding in industrial applications," Nitrex Metal, vol. www.Nitrex.com, pp. 1-6, 1999.

[59] M. Nikolova, P. Danev, I. Dermendjiev and D. Gospodinov, "Vacuum Oxynitrocarburization of ultra-fine electrolytic iron," Procedia Engineering, 2011.

[60] N. M. T. Inc., "www.surfacefinishing.com," Nitrex Metal Technologies Inc., 2012. [Online].

[61] T. Woehrle, A. Leineweber and E. Mittemeijer, "Microstructural and phase evolution of compound layers growing on alpha iron during gaseous nitrocarburizing," Metallurgical and Materials Transactions A, vol. 43, pp. 2401-2413, 2012.

[62] E. Mittemeijer and M. Sommers, "Thermodynamics, kinetics and process control of nitriding," Surface Engineering, vol. 13, no. 6, pp. 483-487, 1997.

[63] M. Sommers and E. Mittemeijer, Surface Engineering, vol. 3, pp. 123-137, 1987.

[64] T. Gressmann, M. Nikolussi, A. Leineweber and E. Mittemeijer, "Formation of massive cementite layers on iron by ferritic carburizing in the additional presence of ammonia," Scripta Materialia, vol. 55, pp. 723-726, 2006.

[65] S. Hoppe, "Fundamentals and applications of teh combination of plasma nitrocarburizing and oxidizing," Surface and Coatings Technology, vol. 98, no. 1-3, pp. 1199-1204, 1998.

[66] I. Lee and K.-H. Jeong, "Plasma post oxidation of plasma nitrocarburized SKD 61 steel," Journal of Materials Science and Technology, vol. 24, no. 1, pp. 136-138, 2008. 
[67] M. Nikolussi, A. Leineweber and E. Mittemeijer, "Microstructure and crystallography of massive cementite layers on ferrite substrates," Acta Materialia, vol. 56, pp. 5837-5844, 2008.

[68] H. Du, Journal of Phase Equilibria, vol. 14, pp. 682-693, 1993.

[69] J. Kuntze, Nitrogen and Carbon in Iron and Steel, Berlin: Academic Verlag, 1990.

[70] Y. Sun, "Enhancement in corrosion resistance of austenitic stainless steels by surface alloying with nitrogen and carbon," Materials Letters, vol. 59, pp. 3410-3413, 2005.

[71] M. Teimouri, M. Ahmadi, N. Pirayesh, M. Khoee, H. Khorsand and S. Mirzamohammadi, "Study of corrosion behaviour of nitrocarburized sintered Astaloy CrM+C," Journal of Alloys and Compounds, vol. 477, no. 1-2, pp. 591-595, 2009.

[72] S. Sahay and K. Mitra, "Cost model based optimization of carburizing operation," Surface Engineering, vol. 20, no. 5, pp. 379-384, 2004.

[73] F. Ernst, Y. Cao and G. Michal, "Carbides in low-temperature carburized stainless steel," Acta Materialia, vol. 52, pp. 1469-1477, 2004.

[74] Y. Cao, F. Ernst and G. Michal, "Colossal carbon supersaturation in austenitic stainless steels carburized at low temperatures," Acta Materialia, vol. 51, pp. 4171-4181, 2003.

[75] I. Jauhari, S. Rozali, N. Masdek and O. Hiroyuki, "Surface properties and activation energy analysis for superplastic carburizing of duplex stainless steel," Materials Science and Engineering A, vol. 466, pp. 230-234, 2007.

[76] C. Scheuer, R. Cardoso, R. Pereira, M. Mafra and S. Brunatto, "Low temperature plasma carburizing of martensitic stainless steel," Materials Science and Engineering, vol. A539, pp. 369-372, 2012.

[77] D. Zhu, W. Liang, Q. Miao, K. Guo and L. Li, "Tribological behaviour of Ti2AlNb by surface plasma carburizing," Advanced Materials Research, Vols. 482-484, pp. 914-918, 2012.

[78] Z. Qin, S. Rong and X. Rong, "GDA and ToF-SIMS of plasma carburized layer on pure titanium with hydrogen free," Advanced Materials Research, Vols. 403-408, pp. 24-27, 2012.

[79] S. Cho, H. Kim, M. Lee, D. Lee and B. Kim, "Direct formation of graphene layers on top of $\mathrm{SiC}$ during the carburization of Si substrate," Current Applied Physics, vol. 12, no. 4, pp. 1088-1091, 2012.

[80] V. Campagna, V. Bowers, D. Northwood, X. Sun and P. Bauerle, "Comparison of carbonitriding and nitrocarburizing on size and shape distortion of plain carbon SAE1010 steel," Surface Engineering, vol. 27, no. 2, pp. 86-91, 2011.

[81] B. Yilbas, S. Akhtar, A. Matthews, C. Karatas and A. Leyland, "Microstructure and thermal stress distributions in laser carbonitriding treatment of Ti-6Al-4V alloy," Journal of Manufacturing Science and Engineering, Transactions of the ASME, vol. 133, no. 2, p. 021013, 2011.

[82] O. Yashiv, "Surface hardening of titanium by noncontact thermodiffusion carbonitriding," Materials Science, vol. 44, no. 5, pp. 659-664, 2008.

[83] M. Ipek, G. Celebi Efe, S. Ozbek, S. Zeytin and C. Bindal, "Investigation of boronizing kinetics of AISI 51100 steel," Journal of Materials Engineering and Performance, vol. 21, no. 5, pp. 733-739, 2012. 
[84] I. Ozbek and C. Bindal, "Kinetics of borided AISI M2 high speed steel," Vacuum, vol. 86, no. 4, pp. 391-397, 2011.

[85] P. Jurci and M. Hudakova, "Diffusion boronizing of H11 hot work tool steel," Journal of Materials Engineering and Performance, vol. 20, no. 7, pp. 1180-1187, 2011.

[86] J. Deebasree, R. Thirumurungesan, P. Shankar and R. Suba Rao, "Laser boriding of austenitic type 304L stainless steel," in International Symposium fo Research Students on Materials Science and Engineering, Chennai, India, 2004.

[87] L. Lei, F. Li, X. Yi, Z. Xi and Z. Fan, "Pack RE-boronizing of TC4 titanium alloy at lower temperature," Heat Treatment of Metals, vol. 37, no. 2, pp. 101-105, 2012.

[88] D. Mu, B. Shen, C. Yang and X. Zhao, "Microstructure analysis of boronized pure nickel using boronizing powders with $\mathrm{SiC}$ as dilutant," Vacuum, vol. 83, no. 12, pp. 1481-1484, 2009.

[89] M. Paczkowska, "Laser boronizing and its potential application," Welding International, vol. 26, no. 4, pp. 251-255, 2012.

[90] "Boronizing -Titancote B," Richter Precision Inc, [Online]. Available: www.richterprecision.com.

[91] A. Bartkowska, A. Pertek, M. Jankowiak and K. Jozwiak, "Laser surface borochromizing of C45 steel," Archives of Metallurgy and Materials, vol. 57, no. 1, pp. 211-214, 2012.

[92] M. Usta, I. Ozbek, C. Bindal, A. Ucisik, S. Ingole and H. Liang, "A comparative study of borided pure niobium, tungsten and chromium," Vacuum, vol. 80, pp. 1321-1325, 2006.

[93] M. Aghaie-Khafri and M. Mohamadpour, "A study of chromo-boronizing on DIN 1.2714 steel by duplex surface treatment," Journal of Metals, vol. 64, no. 6, pp. 694-701, 2012.

[94] Z. Zakhariev and R. Petrova, "Gas phase reactions during simultaneous boronizing and aluminizing of steels," Journal of Alloys and Compounds, vol. 196, pp. 59-62, 1993.

[95] M. Kulka, N. Makuch, A. Pertek and A. Piasecki, "Microstructure and properties of borocarburized and laser-modified 17CrNi6-6 steel," Optics and Laser Technology, vol. 44, no. 4, pp. 872-881, 2011.

[96] A. Pertek and M. Kulka, "Characterization of complex $(B+C)$ diffusion layers formed on chromium and nickel-based low carbon steel," Applied Surface Science, vol. 202, pp. 252260, 2002.

[97] M. Kulka and A. Pertek, "Characterization of complex $(B+C+N)$ diffusion layers formed on chromium and nickel-based low carbon steels," Applied Surface Science, vol. 218, pp. 113-122, 2003.

[98] W. Lee and J. Duh, "Evaluation of microstructures and mechanical properties of chromized steels with different carbon content," Surface and Coatings Technology, Vols. 177-178, pp. 525-531, 2004.

[99] G. Meier, C. Cheng, R. Perkins and W. Bakker, "Diffusion chromizing of ferrous alloys," Surface and Coatings Technology, Vols. 39-40, no. C, pp. 53-64, 1989.

[100] S. Lu, Z. Wang and K. Lu, "Enhanced chromising kinetics of tool steel by means of surface mechanical attrition treatment," Materials Science and Engineering A, vol. 527, pp. 995-1002, 2010. 
[101] O. Ozdemir, S. Sen and U. Sen, "Formation of chromium nitride layers on AISI 1010 stel by nitro-chromizing process," Vacuum, vol. 81, no. 5, pp. 567-570, 2007.

[102] F. Hakami, M. Heydarzadeh, J. Rasizadeh and M. Ebrahimi, "Chromizing of plasma nitrided AISI 1045 steel," Thin Solid Films, vol. 519, no. 20, pp. 6783-6786, 2011.

[103] S. Sen and U. Sen, "The effect of boronizing and borochromizing on tribological performance of AISI 52100 bearing steels," Industrial Lubrication and Tribology, vol. 61, no. 3, pp. 146-153, 2009.

[104] R. Arter, "Japanese technology finds a home in Indiana," Tooling and Production, vol. 56, no. 7, pp. 72-74, 1990.

[105] M. Azizi and M. Soltanieh, "Kinetic study of niobium carbide coating formation on AISI L2 steel using thermo-reactive deposition technique," IJE Transactions B, vol. 23, no. 1, pp. 77-85, 2010.

[106] F. Czerwinski, "The microstructure and internal stress of Fe-Ni nanocrystalline alloys electrodeposited without a stress reliever," Electrochimica Acta, vol. 44, pp. 667-675, 1998.

[107] V. Lee, D. Stinton, C. Berndt, F. Erdogan, Y. Lee and Z. Mutasim, "Concept of functionally graded materials for advanced thermal barrier coating application," Journal of American Ceramic Society, vol. 79, p. 3003, 1996.

[108] F. Czerwinski, "Creating functionally graded microstructures by electrodeposition and diffusion annealing," Plating and Surface Finishing, vol. 87, no. 6, pp. 68-71, 2000.

[109] F. Czerwinski, "Diffusion annealing of Fe-Ni alloy coatings on steel substrate," Journal of Materials Science, vol. 33, pp. 3831-3837, 1998. 